\title{
Tidal dynamics in palaeo-seas in response to changes in physiography, tidal forcing, and bed shear stress
}

Valentin Zuchuat ${ }^{1}$, Elisabeth Steel ${ }^{2}$, Ryan P. Mulligan ${ }^{3}$, Daniel S. Collins ${ }^{4}$, J.A. Mattias Green ${ }^{5}$

${ }^{1}$ Department of Geosciences, University of Oslo, Sem Sælands Vei 1, 0371 Oslo, Norway

${ }^{2}$ Department of Geological Sciences and Geological Engineering, 36 Union Street, Queen's University, Kingston K7L 3N6, Ontario, Canada

${ }^{3}$ Department of Civil Engineering, Ellis Hall, Queen's University, Kingston K7L 3N6, Ontario, Canada

${ }^{4}$ Shell International Limited, Shell Centre, London, SE1 7NA, UK

${ }^{5}$ School of Ocean Sciences, Bangor University, Menai Bridge, Anglesey, LL59 5AB, UK

This preprint is the revised version of our original manuscript. The revised manuscript was submitted to Sedimentology on the $7^{\text {th }}$ July 2021.

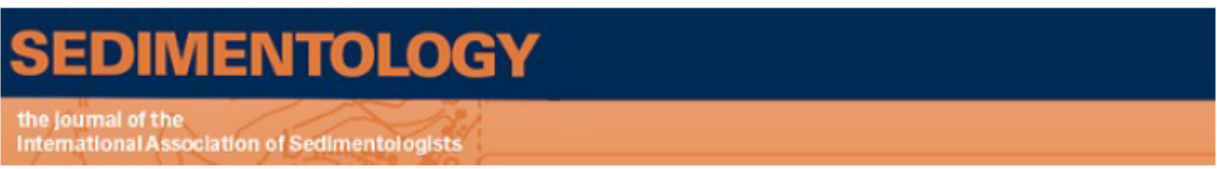

Tidal dynamics in palaeo-seas in response to changes in physiography, tidal forcing, and bed shear stress

\begin{tabular}{|r|l|}
\hline Journal: & Sedimentology \\
\hline Manuscript ID & SED-2020-OM-337.R1 \\
\hline Danuscript Type: & Original Manuscript \\
\hline Author: & n/a \\
\hline Complete List of Authors: & $\begin{array}{l}\text { Zuchuat, Valentin; University of Oslo, Department of Geosciences } \\
\text { Steel, Elisabeth; Queen's University, Geological Sciences and Geological } \\
\text { Engineering } \\
\text { Mulligan, Ryan; Queen's University Department of Civil Engineering } \\
\text { Collins, Daniel; Shell International Limited } \\
\text { Green, J.A. Mattias; Bangor University School of Ocean Sciences }\end{array}$ \\
\hline Keywords: & $\begin{array}{l}\text { Numerical modelling, palaeoceanography, tidal deposits, relative sea- } \\
\text { level change, non-uniqueness, sequence stratigraphy, Upper Jurassic, } \\
\text { Curtis Formation }\end{array}$ \\
\hline & \\
\hline $\begin{array}{l}\text { Note: The following files were submitted by the author for peer review, but marked to be sent in Off- } \\
\text { Line. }\end{array}$ &
\end{tabular}




\title{
Tidal dynamics in palaeo-seas in response to changes in physiography, tidal forcing, and bed shear stress
}

\author{
Valentin Zuchuat ${ }^{1}$, Elisabeth Steel ${ }^{2}$, Ryan P. Mulligan ${ }^{3}$, Daniel S. Collins ${ }^{4}$, J.A. Mattias Green ${ }^{5}$ \\ ${ }^{1}$ Department of Geosciences, University of Oslo, Sem Sælands Vei 1, 0371 Oslo, Norway \\ ${ }^{2}$ Department of Geological Sciences and Geological Engineering, 36 Union Street, Queen's University, \\ Kingston K7L 3N6, Ontario, Canada \\ ${ }^{3}$ Department of Civil Engineering, Ellis Hall, Queen's University, Kingston K7L 3N6, Ontario, Canada \\ ${ }^{4}$ Shell International Limited, Shell Centre, London, SE1 7NA, UK \\ ${ }^{5}$ School of Ocean Sciences, Bangor University, Menai Bridge, Anglesey, LL59 5AB, UK
}

\section{Abstract}

Simulating hydrodynamic conditions in palaeo-ocean basins is needed to better understand the effects of tidal forcing on the sedimentary record. When combined with sedimentary analyses, hydrodynamic modelling can help decipher complex temporal and spatial evolution sedimentation in tide-dominated palaeo-ocean basins. Herein, palaeotidal modelling of the epicontinental, Upper Jurassic (160 Ma, lower Oxfordian) Sundance and Curtis Seas sheds lights on regional-scale variations in tidal dynamics in response to changes in ocean tidal forcing, physiographic configuration, and bottom drag coefficient. A numerical model forced with an M2 tidal constituent at the open boundary shows that the magnitude and the location of tidal amplification, and the variability in current velocity and bed shear stress in the basin were controlled by palaeophysiography. Numerical results obtained using a depth of $600 \mathrm{~m}$ at the ocean boundary of the system enable the prediction of major facies trends observed in the lower Curtis Formation. The simulation results also highlight that certain palaeophysiographic configurations can either permit or prevent tidal resonance, leading to an overall amplification or dampening of tides across the basin. Furthermore, some palaeophysiographic configurations generated additional tidal harmonics in specific parts of the basins. Consequently, similar sedimentary successions can emerge from a variety of sea-level scenarios, and variety of sedimentary successions may be deposited in different parts of the basin in any given sea level scenario. These results suggest that the interpretation of sedimentary successions deposited in tidedominated basins should consider changes in tidal dynamics in response to sea level and physiographic variations.

Key words: Numerical modelling, palaeoceanography, tidal deposits, relative sea-level change, nonuniqueness, sequence stratigraphy, Upper Jurassic, Curtis Formation 


\section{Introduction}

Tides have been observed, measured, and predicted for centuries (if not millennia) by seafarers across the world (Cartwright, 2001) despite a very limited understanding of the astronomical mechanics behind them. It is now well understood that variations in the force of gravity caused by periodic motions of the Moon, Earth and Sun generate different components of the observed tidal water level elevations. Today, 630 tidal harmonic constituents (Simon and Page, 2017) have been identified and can be used to mathematically solve, model, and predict the propagation of modern tides, although far fewer constituents are normally used for predictions at specific locations (e.g. Fang et al., 1999; Hess, 2003; Pelling et al., 2013; Ashall et al., 2016; Kresning et al., 2019; Mulligan et al., 2019a). Of these, the semi-diurnal M2-lunar constituent is commonly the most important, which, when combined with the strongest solar constituent S2, causes neap-spring tidal cycles (Parker, 2007).

There is no shortage of tidal evidence in the ancient rock record (e.g. Eriksson, 1977; Kvale \& Archer, 1991; Räsänen et al., 1995; Kvale, 2006; De Raaf \& Boersma, 2007; James \& Dalrymple, 2010; Davis \& Dalrymple, 2012; Longhitano et al., 2012; Gugliotta et al., 2016; Rossi et al., 2016; Fritzen et al., 2019; Collins et al., 2020; Phillips et al., 2020), although some of the concepts developed from the study of ancient tidally-influenced sedimentary strata can be inconsistent with phenomena recognised in modern tidal environments (see discussion in Gugliotta \& Saito, 2019; Cosma et al., 2020; Finotello et al., 2020). Numerical modelling of ancient basins (e.g. Wells et al., 2010; Hill et al., 2011; Mitchell et al., 2011; Collins et al., 2018; Dean et al., 2019; Green et al., 2020) can help to test hypotheses formulated from the study of the rock record, reduce discrepancies between interpreted ancient and modern tides and tidal deposits, and improve the calibration of ancient tidal signals to astronomic parameters. Complementarily, the rock record can help to constrain model inputs and results (Ward et al., 2015; Dean et al., 2019; Collins et al., submitted; Byrne et al., 2020; Green et al., 2020), and exclude anomalous "numerically-viable" simulations (Ward et al., 2020). The integration of field data and numerical modelling also helps to test, quantify, and visualise the spatio-temporal changes in tidal processes resulting from changes in basin configuration (Collins et al., submitted). For instance, in depositional basins, the sedimentary record can be interpreted and numerical models can be used to confirm or enhance knowledge of these systems (e.g. Mallinson et al., 2018; Mulligan et al., 2020). This increased knowledge of past basins will help improve understanding of how tidal processes will evolve in response to today's sea-level rise, including assisting coastal areas in their planning by demonstrating how and where the tidal regime will significantly change.

The primary aim of this paper is to improve the interpretation of the sedimentary record by studying the impact of palaeophysiographic configuration (PPC), initial open-ocean tidal forcing, and bed shear stress on the behaviour of tides across an epicontinental sea. Through a series of numerical modelling experiments, this study highlights the consequences that variations in these initial conditions can have on interpreting the history and sequence stratigraphy of tidally-influenced sedimentary successions. 
Specific objectives are to: (i) simulate the propagation of tides in the Jurassic Sundance and Curtis seas in present day Utah, USA (Fig. 1) using a variation of potential PPC, initial open-ocean tidal forcing inputs, and bed shear stress values to assess their impact on tidal processes; (ii) compare sediment distribution proxies derived from simulated flow speed and bed shear stress values (Ward et al., 2015; 2020) to deposits of the Upper Jurassic Curtis Formation of the innermost Curtis Sea; and (iii) analyse the implications of these simulation results on basin history and sequence stratigraphy of similar systems.

\section{Geological context}

During the Middle and Upper Jurassic, the $2500 \mathrm{~km}$-long Sundance Sea (Fig. 1), also known as the proto-Western Interior Seaway (Blakey, 2014), developed in a retroarc foreland basin (Brenner \& Peterson, 1994; Bjerrum \& Dorsey 1995). This seaway covered an area spanning between present day British Columbia, where it was connected to the Pacific Ocean, and Wyoming to the SE (Imlay, 1952; Imlay, 1980; Blakey, 2014). During the Callovian and Oxfordian Stages, the Sundance Sea periodically extended an additional 1500 km south-westward (Imlay, 1952; Pipiringos \& O'Sullivan, 1978; Peterson \& Pipiringos, 1979; Imlay, 1980; Kreisa \& Moila, 1986; Caputo \& Pryor, 1991; Anderson \& Lucas, 1994; Brenner \& Peterson, 1994; Peterson, 1994; Wilcox \& Curie, 2008; Hintze \& Kowallis, 2009; Sprinkel et al., 2011; Thorman, 2011; Doelling et al., 2013; Danise \& Holland, 2017, 2018; Zuchuat et al., 2018; 2019a; 2019b; Danise et al., 2020), flooding the SSW-NNE-oriented retroarc foreland basin known as the Utah-Idaho Trough (Bjerrum \& Dorsey, 1995), which developed at the foot of the Elko Orogeny (Thorman, 2011; Anderson, 2015). These repeated southwestward incursions (Zuchuat et al., 2019a) from the Sundance Sea led to the deposition of two shallow-marine sedimentary units that outcrop today in east-central Utah: The Callovian Carmel Formation and the Oxfordian Curtis Formation. The Carmel Formation (Gilluly \& Reeside, 1928) primarily consists of limestone and evaporites, and was deposited as the Carmel Sea transgressed over the arid continental Temple Cap Formation (Doelling et al., 2013). The arid coastal plain deposits of the Entrada Sandstone were deposited during the subsequent regression (Crabaugh and Kocurek 1993; Peterson, 1994; CarrCrabaugh and Kocurek 1998). A second, pulsed marine transgression occurred during the Oxfordian (Wilcox \& Curie, 2008; Zuchuat et al., 2019a), and led to the deposition of the siliciclastic-rich Curtis Formation (Fig. 2; Gilluly \& Reeside, 1928). The Curtis Formation is conformably overlain by arid mudflats of the Summerville Formation (Gilluly \& Reeside, 1928), which developed as the Curtis Sea regressed towards the NE (Caputo \& Pryor 1991; Wilcox \& Curie, 2008; Zuchuat et al., 2019a). 


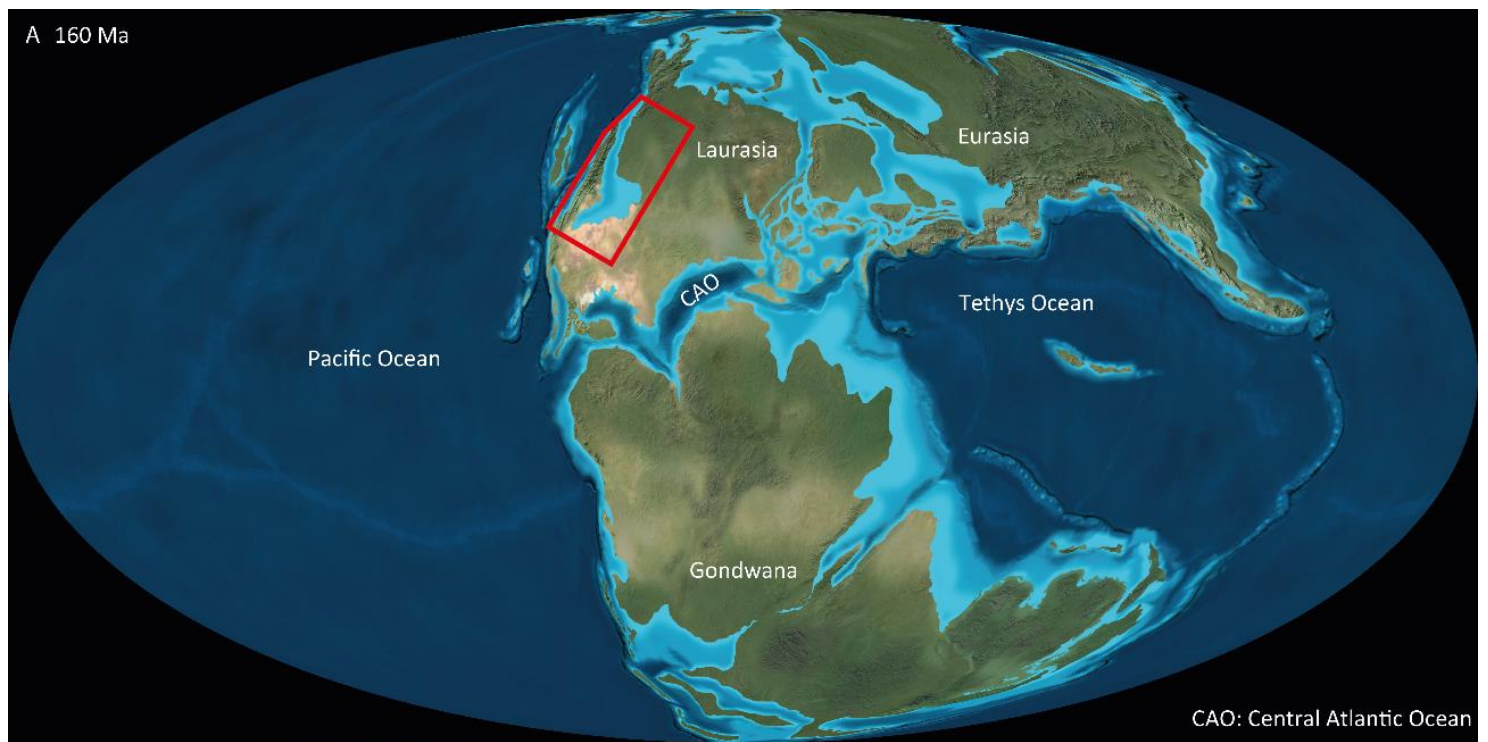

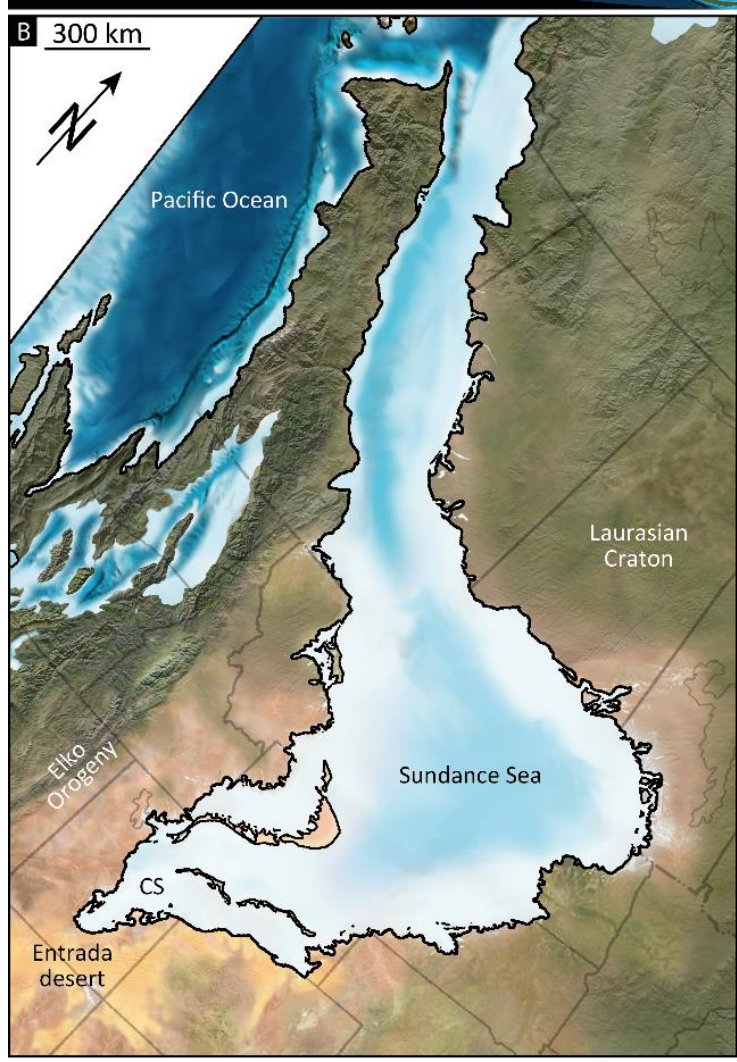

Key locations

Ocean North (ON) Ocean West (OW) Corridor Middle West (CMW) Corridor Middle Middle (CMM) Corridor Middle East (CME)
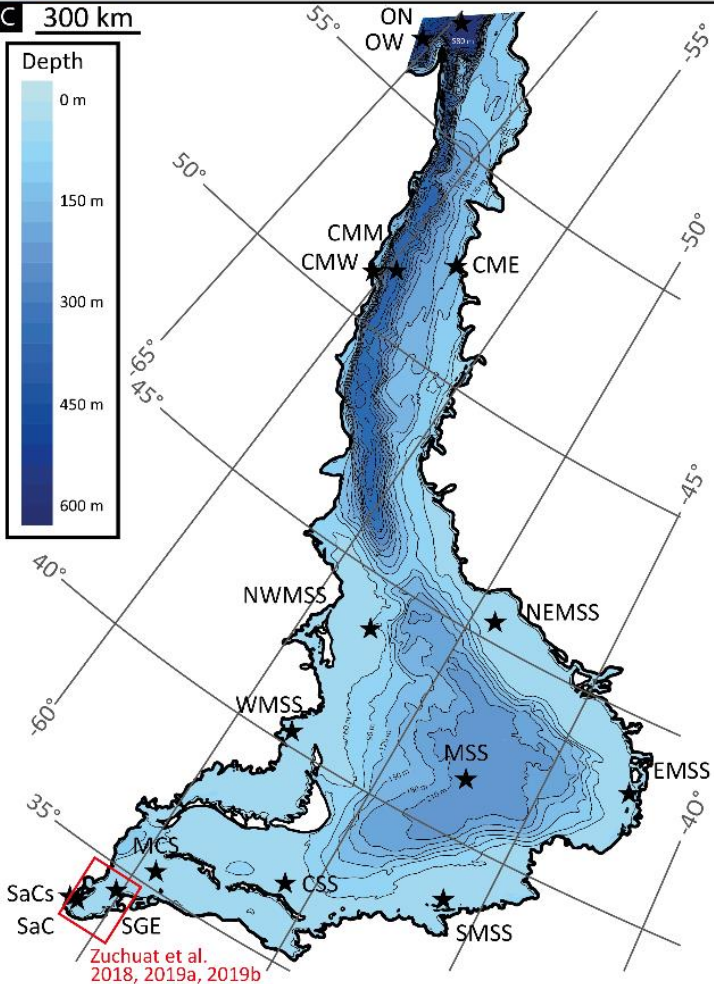

2018, 2019a, 2019b
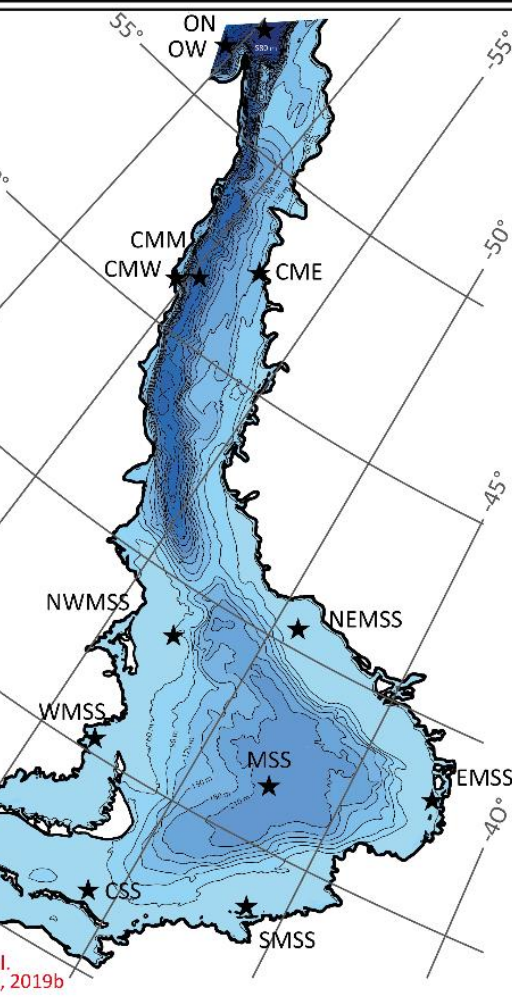

$\circ$ 
common heterolithic lithologies, inclined heterolithic strata, rhythmites, tidal bundles and flaser bedding (both of which are often combined with additional indications of periodic waxing and waning of the flow, i.e. thickening and thinning of the strata and foresets). There is also robust sedimentary and statistical evidence of recurrent flow reversals, comprising reactivation surfaces in compound dunes (some associated with subordinate counter-current ripples at their toes), bidirectionallyaccreting bar-forms, and herringbone cross-stratification (Zuchuat et al., 2018). Indicators of wave activity are extremely scarce in the Curtis Formation, although it does not necessarily imply that these processes were completely inactive at the time of deposition (van Yperen et al., 2020). Nevertheless, the lack of preservation of wave markers associated with the abundance of tidal indicators suggest tides were the more dominant process in the Curtis Sea. Additionally, the Curtis Sea was bounded by the arid Entrada continental plains, in which no perennial fluvial systems developed, therefore drastically limiting the possible influence of rivers on the deposition of the Curtis Formation (Kreisa \& Moila, 1986; Caputo \& Pryor 1991; Wilcox \& Curie, 2008; Doelling et al., 2013; Zuchuat et al., 2018; 2019a; 2019b).

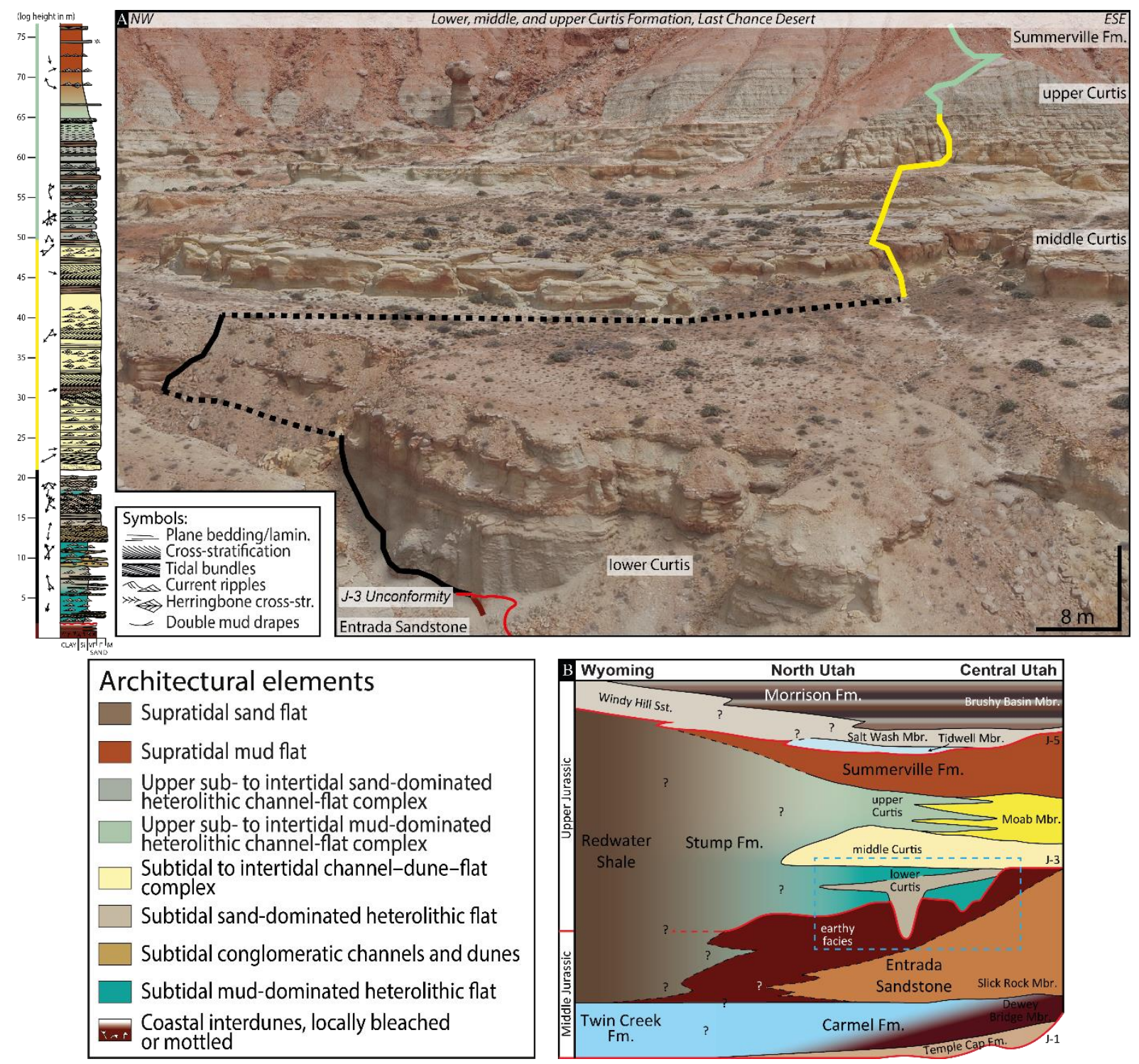


Fig. 2 - A) Photograph of the Curtis Formation accompanied by a sedimentary log detailing the stratigraphic architecture of the formation. The Curtis Formation is subdivided into three informal subunits: the thinly-bedded, heterolithic, lower Curtis (black trace), the well-sorted, cross-stratified and amalgamated, middle Curtis (yellow trace), and the fining-upward, tabular, upper Curtis (light green trace; Zuchuat et al., 2018). This paper will focus on the development of the lower Curtis only. B) Schematic panel displaying the part of the Middle and Upper Jurassic lithostratigraphy outcropping between Central Utah and Wyoming (after Doelling et al., 2013; Danise \& Holland, 2017; Zuchuat et al., 2018; Danise et al., 2020). Note that the J3 and the J-5 Unconformities are not regarded as unconformities sensu stricto anymore, but rather as a highly diachronous transgressive surface (Zuchuat et al., 2019a), and the product of a prograding braided fluvio-deltaic system unimpacted by relative sea-level fall (Danise et al., 2020), respectively.

The correlative units of the Curtis-Summerville interval towards the Sundance Sea are the Stump Formation (Mansfield \& Roundy, 1916; Pipiringos \& Imlay, 1979; Imlay, 1980; Patterson-Wittstrom, 1980; Wilcox \& Currie, 2008; Jensen et al., 2016; Kowallis et al., 2018) and the Redwater Shale Member of the Sundance Formation (Imlay, 1947, 1980; Patterson-Wittstrom, 1980; Uhlir et al., 1988). The mudstones of the Redwater Shale Member record deposition in the deeper part of the Sundance Sea (Imlay, 1980; Danise \& Holland, 2018), and thus experienced limited tidal influence. In contrast, the heterolithic Stump Formation, which mostly consists of glauconitic sandstone, muddy siltstone, and oolitic limestone (Pipiringos \& Imlay, 1979; Imlay, 1980; Patterson-Wittstrom, 1980; Jensen et al., 2016; Kowallis et al., 2018), was influenced by tidal processes at the time of deposition (Wilcox \& Currie, 2008). North of the central Sundance Sea and up to the mouth of the system, the climate was more temperate than the arid climate prevailing around the Curtis Sea (Sellwood and Valdes, 2006; Uhl et al., 2012). As a result, fluvial processes might have impacted the coastal dynamics locally, but the lack of geological record prevents any interpretation of where and how strong these fluvial processes were.

The lack of high-resolution biostratigraphy and absolute dating of Curtis-Summerville interval makes precise regional correlation between units in the Curtis Sea and Sundance Sea challenging. Nevertheless, as the Oxfordian regression of the Curtis Sea persisted and the climate became more humid (Demko et al., 2004; Boucot et al., 2013; Danise \& Holland, 2017), the shoreline developed as a tide-dominated deltaic system (Holland \& Wright, 2020). These sandstone-dominated strata, which belong to the Windy Hill Member of the Morrison Formation (Pipiringos, 1968), indicate that tidal currents lingered despite a shrinking sea (Uhlir et al., 1988; Danise \& Holland, 2018; Holland \& Wright, 2020). 


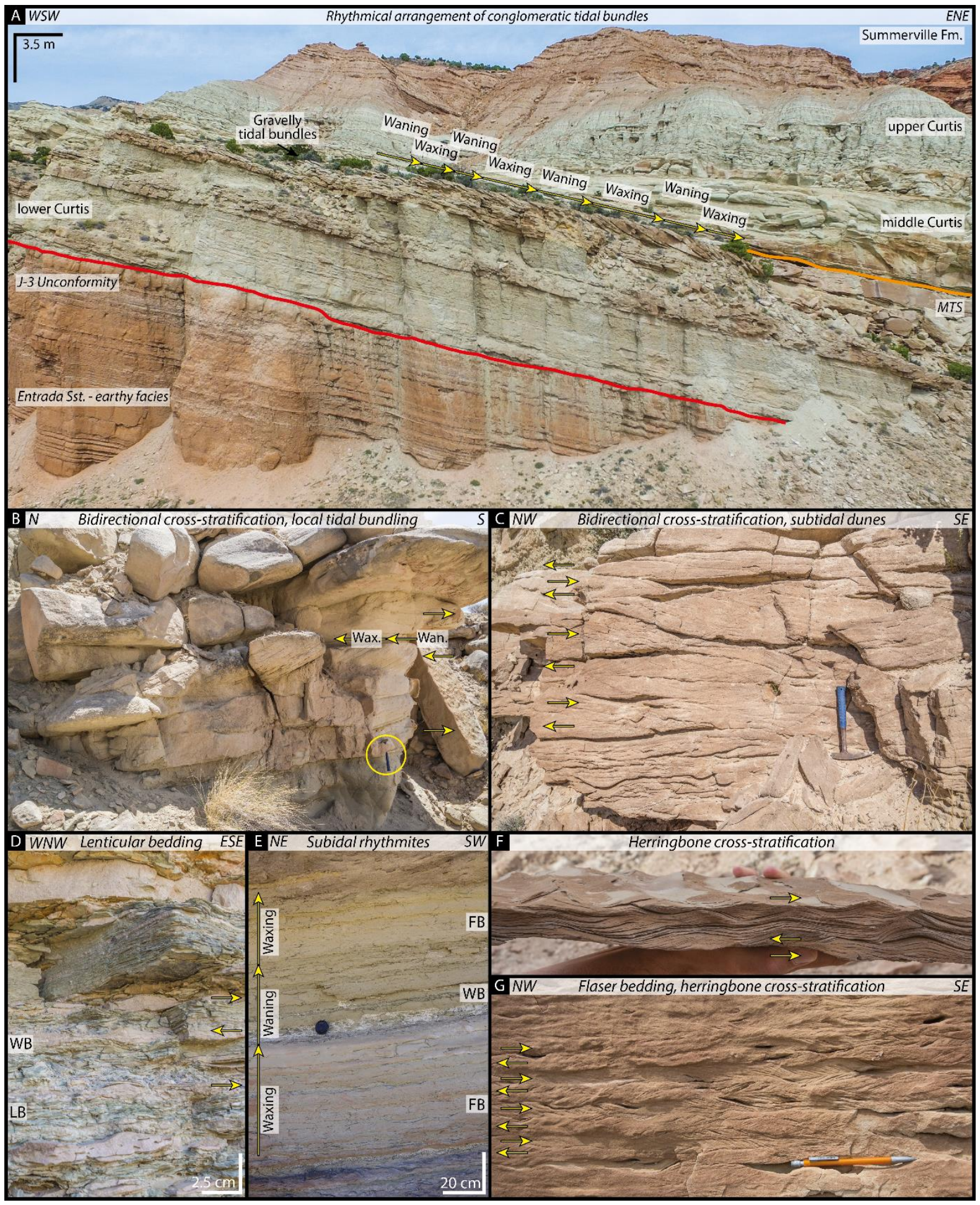

Fig. 3 - Example of sedimentary bedforms diagnostic of tidal currents. A) Rhythmical development of conglomeratic tidal bundles following phases of waxing and waning of tidal currents. B) Bidirectional cross-stratification in stacked, threedimensional (3D) subtidal dunes, with local waxing-waning architecture. Hammer for scale (yellow circle, $32 \mathrm{~cm} l o n g$ ). C) Bidirectional cross-stratification in 3D subtidal dunes. Hammer for scale. D) Heterolithic strata, deposited as lenticular (LB) and wavy bedding (WB), with bidirectional, ripple cross-stratified sandstone lenses. E) Subtidal rhythmites, testifying to phases of waxing and waning tidal currents. F) Bidirectional ripple cross-stratified sandstone bed (herringbone crossstratification). Hand for scale. G) Flaser bedded sandstone, with bidirectional ripple cross-stratification. Pencil for scale (ca. $15 \mathrm{~cm}$ long 


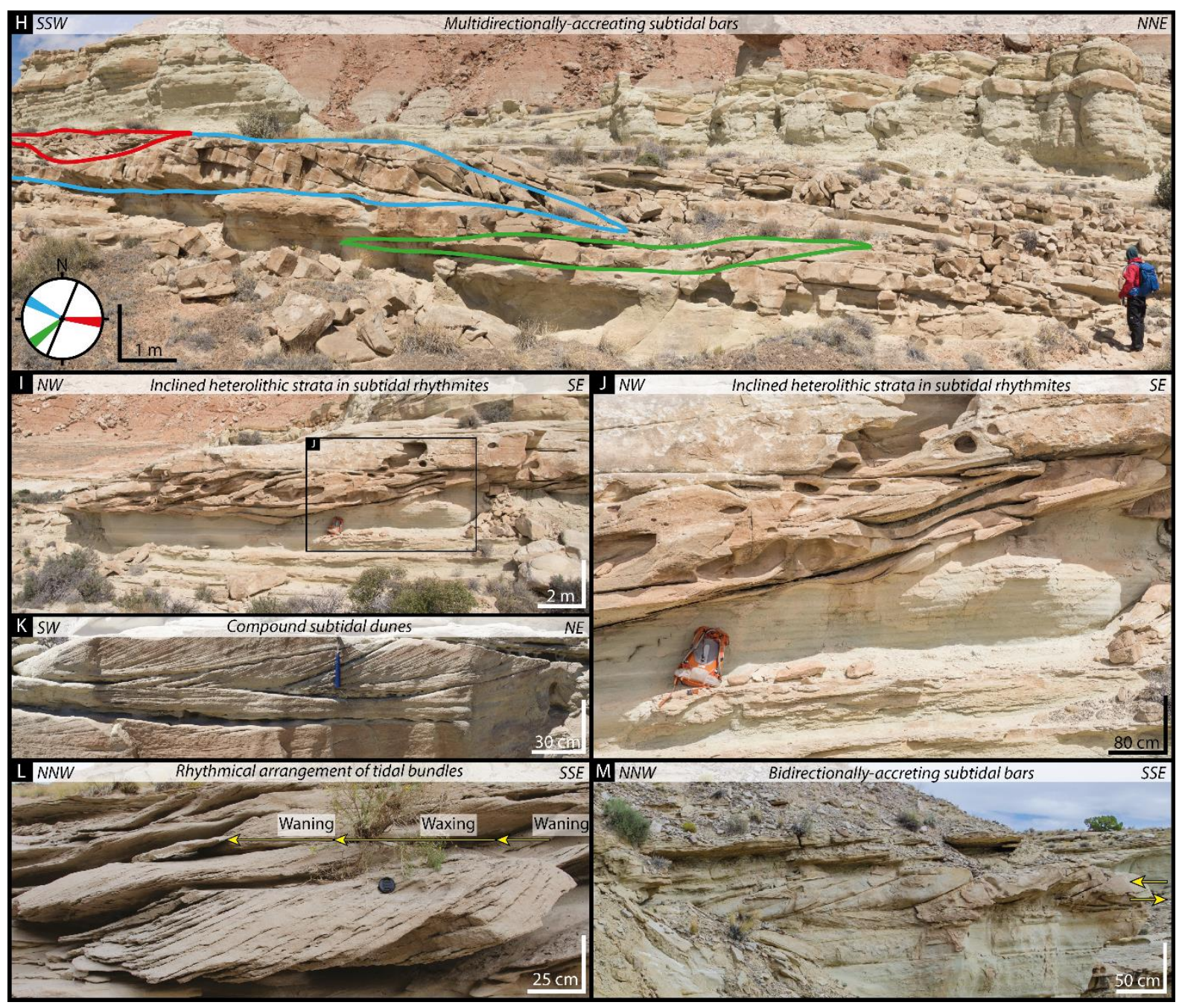

Fig. 3 -(follows) H) Colour-coded, multidirectionally-accreting subtidal bars. The black line on the rose diagram corresponds to the SSW-NNE orientation of the photograph. Geologist for scale $(1.80 \mathrm{~m})$. I-J) Inclined heterolithic strata, product of the lateral migration of the meander of subtidal-channel, incising into subtidal rhythmites. (Backpack for scale, height ca. $75 \mathrm{~cm}$ ). K) Compound, 3D subtidal dune with multiple reactivation surfaces. L) Rhythmical development of sigmoidal tidal bundles following phases of waxing and waning of tidal currents. M) Bidirectional migration of subtidal bars.

\section{Methods}

\section{Numerical Modelling}

The methods employed in this study followed common practice for hydrodynamic modelling in present-day tidal basins (e.g. Hu et al., 2009; Elias et al., 2012; Brown et al., 2014; Mulligan et al., 2015; Mulligan et al., 2019b), however observations of water levels and currents are lacking, and the set-up of the model therefore relied on geological interpretations of palaeo environmental conditions. The modelling of tides in the Upper Jurassic Sundance and Curtis Seas used the Oxfordian palaeogeographical map (Fig. 1) from Blakey's Deeptime Map ${ }^{\mathrm{TM}}$ (Colorado Plateau Geosystems Inc.Maps), which was geo-palaeoreferenced using GPlates (Müller et al., 2018) and projected on a Lambert Conformal Conic projection. Various PPCs were generated by converting the maps to a physiographic raster (Python code; Appendix A) and importing them into Deltares open-source Delft3D numerical modelling software. Delft3D is a three-dimensional hydrodynamic simulation suite used for solving hydrostatic and non-hydrostatic equations (see Delft3D user manual for details), and 
it has been used to model a variety coastal systems, including river deltas, beaches, estuaries, lagoons, and barrier islands-inlet systems (e.g. Hu et al., 2009; Elias et al., 2012; Brown et al., 2014; Mulligan et al., 2015; Mulligan et al., 2019b). Due to the unknown true water depths and the need to investigate different realistic PPC scenarios, a series of different depth grids was generated using the colourgradient in the original paleogeographic map. The shoreline (i.e. lightest colour on the map) is a finite boundary and was assigned a constant depth of $0 \mathrm{~m}$, and the mouth of the system (the darkest map colour) was assigned depths of 300 m, 460 m, 555 m, 600 m, 645 m, 860 m, 1000 m, 1200 m, and 1400 $m$ to generate 9 different depth scenarios (note that the name of each simulation used in this manuscript refers to these maximum depth values). Each depth scenario provided a different basin gradient from the mouth of the system to the inland shoreline, i.e. the shallower the depth at the mouth of the system, the shallower basin gradient was.

The grid used to run the simulations was fixed and structured, and comprised 100,496 cells, which were approximately $3.4 \times 3.4 \mathrm{~km}$ at the northern ocean boundary, and $3.6 \times 5.7 \mathrm{~km}$ in the southernmost part of the study area. The ocean boundary was an open boundary, allowing tidal flows to enter and exit the system. Shoreline boundaries were fitted to the coastline, and the relatively coarse resolution of the grid did not allow for detailed smaller-scale processes such the wetting and drying cycles of intertidal areas or flooding of the land surface to be accurately resolved, however the details of these processes are of lesser importance to the regional scale in this study.

Because it was not possible to know the exact oscillation of the water level or the specific combination of tidal constituents that affected the studied system, the idealized tides were simulated in the basin using the dominant semi-diurnal M2 tidal constituent with the same period as today (i.e., $12.42 \mathrm{hr}$; e.g., Darwin, 1898; Pugh \& Woodworth, 2014;). Doing so allowed for unverifiable assumptions to be kept to a minimum, in line with previous modelling studies (Wells et al., 2005a, b). The idealized approach of the M2 tidal boundary condition therefore enables interpretation of the complex tidal conditions that were generated within the sea. Other parameters such as the gravitational acceleration $\left(g=9.81 \mathrm{~m} / \mathrm{s}^{2}\right)$ and fluid density $\left(\rho=1025 \mathrm{~kg} / \mathrm{m}^{3}\right)$ were held constant. Even though neapspring cycles are recognised in the Curtis Formation (Zuchuat et al., 2018, 2019a), the modelling results did not resolve spring-neap oscillations, which would have required simulate additional tidal constituents.

The simulations were run for 44 days using a 1-minute time step (Fig. 4), which allowed the tides to reach steady-state. The exception was the 1430 m PPC, which was run for 134 days to allow the tides to reach equilibrium. It is suspected that this delay in reaching equilibrium is linked to internally generated oscillations in the basin, but this analysis extends beyond the scope of this paper. An initial tidal amplitude of $0.5 \mathrm{~m}$ was applied at the model boundary at the mouth of the system. This amplitude was selected based on global simulations of the time slice (D. Hadley-Pryce, personal communication). A higher amplitude tidal boundary condition of $2 \mathrm{~m}$ was also used to test how the 
basin would respond to changes in tidal forcing (Fig. 5). The bed shear stress $\tau$ (e.g., Lentz et al. 1999; Wells et al., 2007) was calculated using

$$
\tau=\rho C_{D} \vec{u}|\vec{u}|
$$

where $\rho$ is the fluid density, $\vec{u}$ is the fluid velocity and $C_{D}$ is the bottom drag coefficient. The simulations used a canonical drag coefficient $\left(C_{D}\right)$ value of 0.002 , derived from the default Chézy coefficient in Delft3D of $C_{z}=65 \mathrm{~m}^{1 / 2} / \mathrm{s}$ (e.g., Mulligan et al., 2010) given by:

$$
C_{D}=\frac{g}{C_{z}^{2}}
$$

where, $g$ is the gravitational acceleration. Equation (3) expresses the dissipation rate $D$ (Taylor, 1929) and was calculated for each the 18 simulations at every step of one complete tidal cycle:

$$
D=\rho C_{D}|\vec{u}|^{3}
$$

where $\rho$ is water density, $C d$ is the drag coefficient, and $u$ is the speed of the current. Subsequently, a 1-tidal-cycle-average dissipation rate was calculated for each model observation site in the Curtis Sea before being averaged across the Curtis Sea for each depth scenario (Table 1).

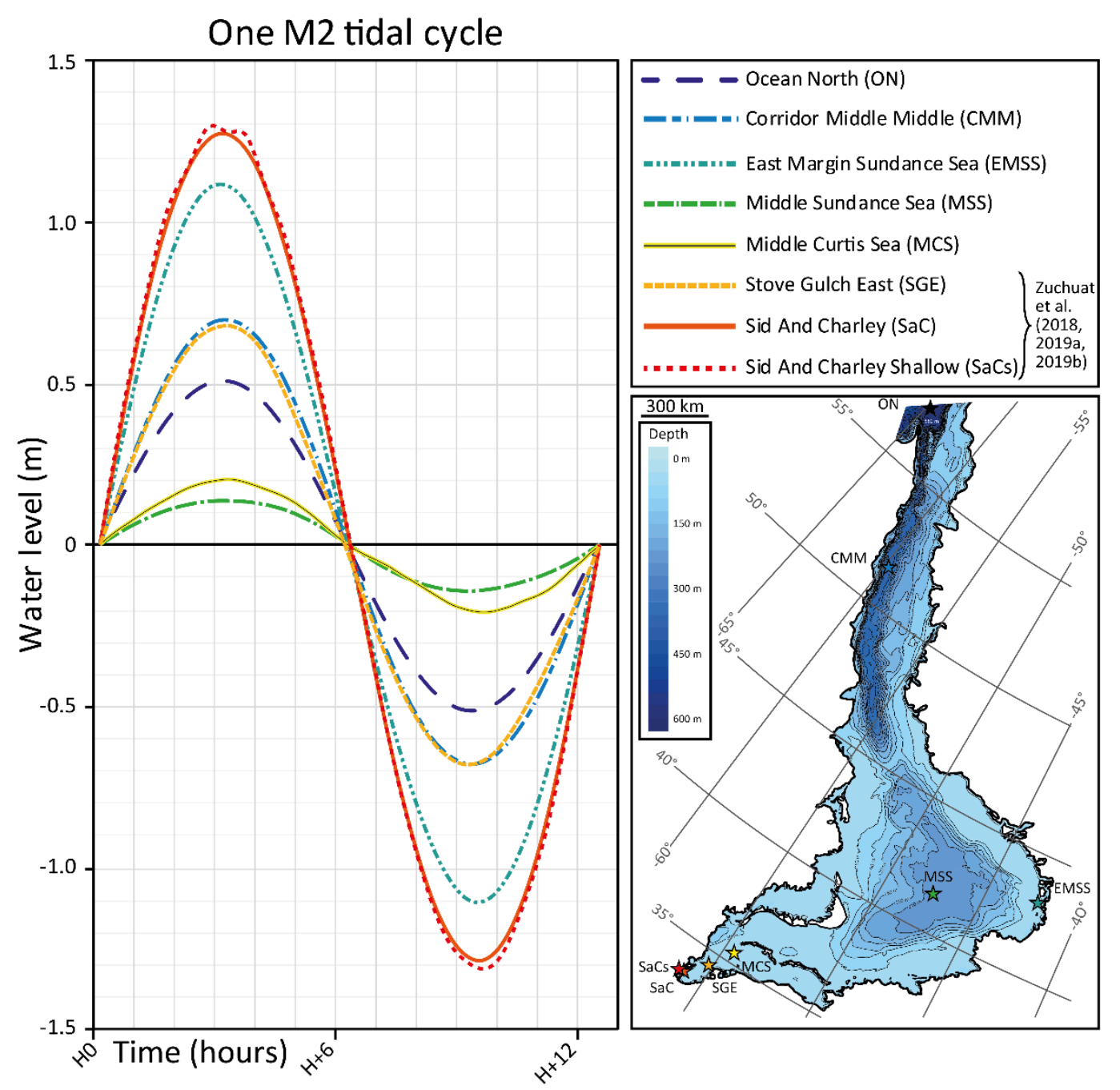

Fig. 4 - Graph showing the simulated tidal amplitude (TA) over one M2 tidal cycle at 8 key localities of the Sundance and Curtis Seas, using the $600 \mathrm{~m}$ PPC. With an initial open-ocean tidal forcing of $0.5 \mathrm{~m}$ at the mouth of the system (ON), the tides are amplified by $162 \%$ in the inner parts of the Curtis Sea, reaching $1.31 \mathrm{~m}$ at SaCs. 
Using the $600 \mathrm{~m}$ depth scenario and a $0.5 \mathrm{~m}$ initial tidal forcing, two additional simulations were run using a high and a low $C_{D}$-value in order to test the sensitivity of the model to changes in the drag coefficient. The high $C_{D}$-value of 0.004 corresponds to $C_{Z}=46 \mathrm{~m}^{1 / 2} / \mathrm{s}$; and the low $C_{D}$-value of 0.001 equates to $C_{z}=92 \mathrm{~m}^{1 / 2} / \mathrm{s}$.

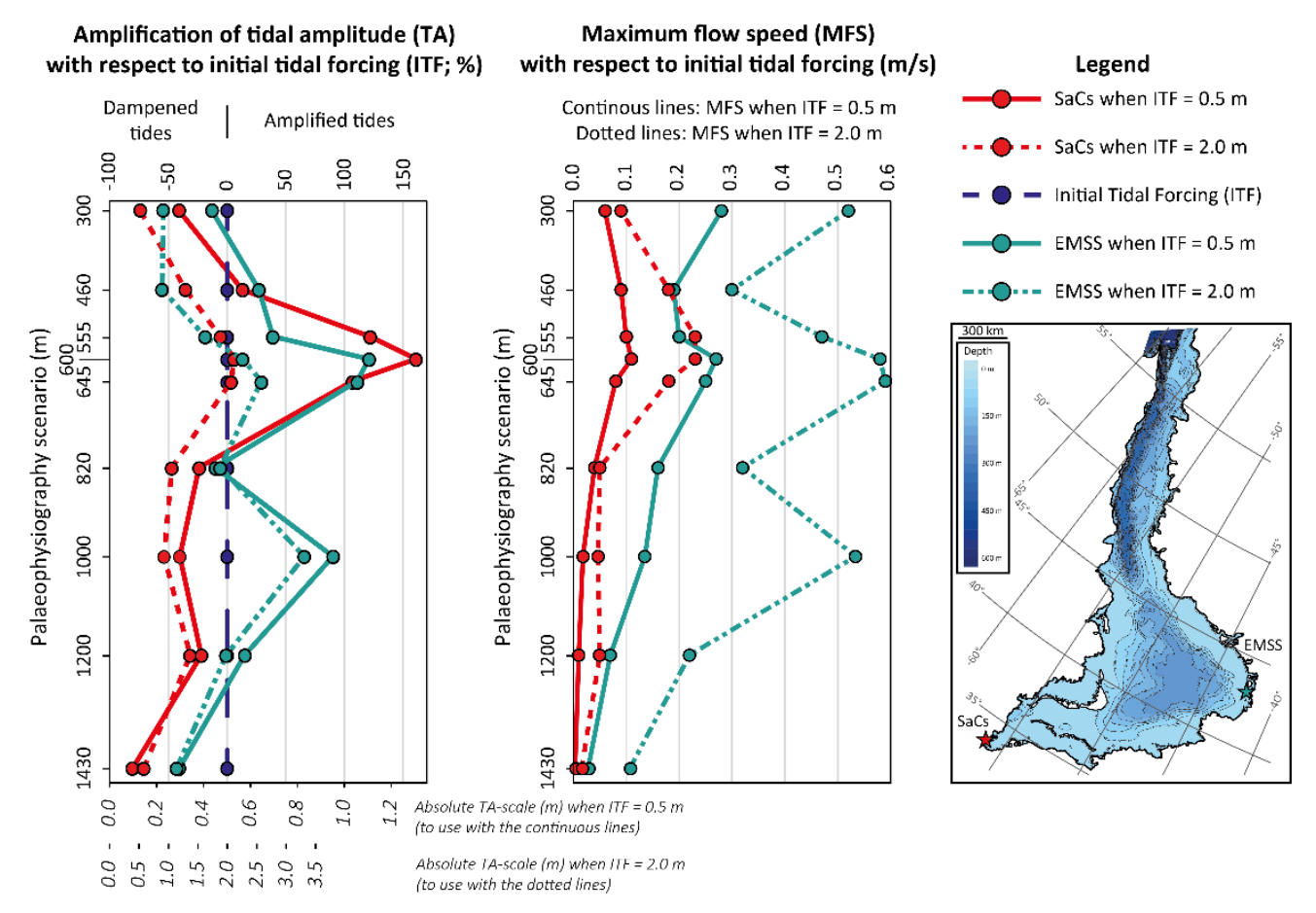

\begin{tabular}{|c|c|c|c|c|c|c|c|c|}
\hline \multicolumn{9}{|c|}{ Sid and Charley Shallow (SaCs) } \\
\hline \multirow[b]{2}{*}{$\begin{array}{c}\text { Depth } \\
\text { scenario }\end{array}$} & \multicolumn{3}{|c|}{ Initial Tidal Forcing $=0.5 \mathrm{~m}$} & \multicolumn{3}{|c|}{ Initial Tidal Forcing $=2 \mathrm{~m}$} & \multirow{2}{*}{$\begin{array}{l}\text { Tidal Amplitude } \\
\text { Increase Factor }\end{array}$} & \multirow[b]{2}{*}{$\begin{array}{l}\text { Maximum Flow Speed } \\
\text { Increase Factor }\end{array}$} \\
\hline & \begin{tabular}{|c} 
Tidal Amplitude \\
(m)
\end{tabular} & $\begin{array}{l}\text { \% of Initial Tidal } \\
\text { Forcing } \\
\end{array}$ & $\begin{array}{c}\text { Maximum Flow Speed } \\
(\mathrm{m} / \mathrm{s})\end{array}$ & $\begin{array}{c}\text { Tidal Amplitude } \\
(\mathrm{m})\end{array}$ & $\begin{array}{l}\text { \% of Initial Tidal } \\
\quad \text { Forcing } \\
\end{array}$ & $\begin{array}{c}\text { Maximum Flow Speed } \\
(\mathrm{m} / \mathrm{s})\end{array}$ & & \\
\hline $300 \mathrm{~m}$ & 0.30 & 59.0 & 0.06 & 0.50 & 24.8 & 0.090 & 0.42 & 1.50 \\
\hline $460 \mathrm{~m}$ & 0.57 & 113.0 & 0.09 & 1.27 & 63.5 & 0.180 & 0.56 & 2.00 \\
\hline $555 \mathrm{~m}$ & 1.11 & 221.9 & 0.10 & 1.87 & 93.5 & 0.230 & 0.42 & 2.30 \\
\hline $600 \mathrm{~m}$ & 1.31 & 261.0 & 0.11 & 2.10 & 105.0 & 0.230 & 0.40 & 2.09 \\
\hline $645 \mathrm{~m}$ & 1.04 & 207.0 & 0.08 & 2.06 & 102.8 & 0.180 & 0.50 & 2.25 \\
\hline $820 \mathrm{~m}$ & 0.38 & 76.0 & 0.04 & 1.04 & 51.8 & 0.050 & 0.68 & 1.25 \\
\hline $1000 \mathrm{~m}$ & 0.30 & 59.5 & 0.02 & 0.90 & 45.2 & 0.047 & 0.76 & 2.58 \\
\hline $1200 \mathrm{~m}$ & 0.39 & 78.0 & 0.01 & 1.35 & 67.5 & 0.050 & 0.87 & 5.00 \\
\hline $1430 \mathrm{~m}$ & 0.10 & 19.1 & 0.003 & 0.55 & 27.7 & 0.015 & 1.45 & 4.97 \\
\hline
\end{tabular}

\begin{tabular}{|c|c|c|c|c|c|c|c|c|}
\hline \multicolumn{9}{|c|}{ East Margin Sundance Sea (EMSS) } \\
\hline \multirow[b]{2}{*}{$\begin{array}{c}\text { Depth } \\
\text { scenario }\end{array}$} & \multicolumn{3}{|c|}{ Initial Tidal Forcing $=0.5 \mathrm{~m}$} & \multicolumn{3}{|c|}{ Initial Tidal Forcing $=2 \mathrm{~m}$} & \multirow[b]{2}{*}{$\begin{array}{l}\text { Tidal Amplitude } \\
\text { Increase Factor }\end{array}$} & \multirow{2}{*}{$\begin{array}{l}\text { Maximum Flow Speed } \\
\text { Increase Factor }\end{array}$} \\
\hline & $\begin{array}{c}\text { Tidal Amplitude } \\
(\mathrm{m})\end{array}$ & $\begin{array}{l}\text { \% of Initial Tidal } \\
\text { Forcing }\end{array}$ & $\begin{array}{c}\text { Maximum Flow Speed } \\
(\mathrm{m} / \mathrm{s})\end{array}$ & $\begin{array}{c}\text { Tidal Amplitude } \\
(\mathrm{m})\end{array}$ & $\begin{array}{c}\text { \% of initial Tidal } \\
\text { Forcing }\end{array}$ & $\begin{array}{c}\text { Maximum flow Speed } \\
(\mathrm{m} / \mathrm{s})\end{array}$ & & \\
\hline $300 \mathrm{~m}$ & 0.44 & 87.0 & 0.28 & 0.89 & 44.5 & 0.520 & 0.51 & 1.86 \\
\hline $460 \mathrm{~m}$ & 0.64 & 127.0 & 0.19 & 0.87 & 43.5 & 0.300 & 0.34 & 1.58 \\
\hline $555 \mathrm{~m}$ & 0.70 & 139.0 & 0.20 & 1.61 & 80.5 & 0.470 & 0.58 & 2.35 \\
\hline $600 \mathrm{~m}$ & 1.11 & 221.0 & 0.27 & 2.25 & 112.5 & 0.580 & 0.51 & 2.15 \\
\hline $645 \mathrm{~m}$ & 1.06 & 211.0 & 0.25 & 2.57 & 128.5 & 0.590 & 0.61 & 2.36 \\
\hline $820 \mathrm{~m}$ & 0.45 & 90.0 & 0.16 & 1.87 & 93.3 & 0.320 & 1.04 & 2.00 \\
\hline $1000 \mathrm{~m}$ & 0.95 & 190.2 & 0.14 & 3.31 & 165.4 & 0.534 & 0.87 & 3.95 \\
\hline $1200 \mathrm{~m}$ & 0.58 & 115.0 & 0.07 & 1.97 & 98.3 & 0.220 & 0.85 & 3.14 \\
\hline $1430 \mathrm{~m}$ & 0.29 & 58.9 & 0.03 & 1.12 & 55.8 & 0.107 & 0.95 & 3.83 \\
\hline
\end{tabular}

Fig. 5 - Tidal amplitude (TA) and maximum flow speed (MFS) at SaCS and EMSS, changing as a function of varying the initial open-ocean tidal forcing.

In addition to the collection of basin-wide data at every step of the simulation (Fig. 6, 7), 34 additional artificial "observation sites" were positioned in the model domain across the seas to monitor and collect water level, flow speed, and bed shear stress values, of which 16 representative sites (Fig. 1) were actively used to analyse simulation results. Of these 34 observation sites, eight are used here to highlight diagnostic behaviours of the tides across the basin (Fig. 4, 8). Note that the maximum water level amplitude across the domain (Fig. 6C) was computed by comparing 47 maps over 47 consecutive hours. 
Table 1 - Comparison between average dissipation values calculated for each palaeophysiography-scenario for a $0.5 \mathrm{~m}$ initial open-ocean tidal forcing and a 2.0 m open-ocean tidal forcing, showing that the dissipation rate is at least 11.5 times stronger with an initial TA four times higher. This increase factor varies significantly and non-linearly, depending on the palaeophysiography.

\begin{tabular}{|c|c|c|c|}
\hline $\begin{array}{l}\text { Depth } \\
\text { scenario }\end{array}$ & $\begin{array}{l}\text { Basin-averaged } \\
D^{*}, 0.5 \mathrm{~m} \text { ITF }\end{array}$ & $\begin{array}{l}\text { Basin-averaged } \\
D^{*}, 2 \mathrm{~m} \text { ITF }\end{array}$ & Increase factor \\
\hline $1430 \mathrm{~m}$ & 0.00001 & 0.00076 & 54.56 \\
\hline $1200 m$ & 0.00028 & 0.00653 & 23.18 \\
\hline $1000 m$ & 0.00073 & 0.00879 & 12.11 \\
\hline $820 m$ & 0.00019 & 0.00701 & 37.51 \\
\hline $645 \mathrm{~m}$ & 0.00104 & 0.01242 & 11.96 \\
\hline $600 \mathrm{~m}$ & 0.00425 & 0.04915 & 11.55 \\
\hline $555 \mathrm{~m}$ & 0.00172 & 0.04310 & 25.11 \\
\hline $460 \mathrm{~m}$ & 0.00043 & 0.01057 & 24.44 \\
\hline $300 \mathrm{~m}$ & 0.00017 & 0.00729 & 43.96 \\
\hline
\end{tabular}

* Calculated using Equations (1), (2), and (3)

ITF: Initial, open-ocean tidal forcing

\section{Simulation results}

Here, we focus on the nine simulations run with an initial tidal forcing of $0.5 \mathrm{~m}$ (Fig. 4, 6, 7, 8). The results of the simulations run with an initial tidal forcing of $2 \mathrm{~m}$ are available as supplementary material (Appendix B).

\section{Tidal characteristics, $600 \mathrm{~m}$ depth scenario}

In the $600 \mathrm{~m}$ depth scenario, the simulated tidal amplitudes showed a 10-minute tidal asymmetry in most of the basin (Fig. 4); it is only in the innermost parts of the Curtis sea that this is not the case. This asymmetry means that the ebb flow lasted 10 minutes longer than the flood flow (Fig. 4).

The tidal circulation in the central, southern, and eastern parts of the Sundance Sea was centred on an amphidromic point ( $46^{\circ} \mathrm{W}, 42^{\circ} \mathrm{N}$; Fig. $6 \mathrm{C}$; see also the animated abstract available with the online version of this manuscript). The area between the central part of the Sundance Sea and the Curtis Sea comprised a number of islands and inlets that separated the main water body into various sub-basins (Fig. 1). This configuration of barriers and narrow openings strongly affected the tidal propagation and hindered the development of an amphidromic circulation, despite the dimensions of the basin theoretically permitting it as the Rossby Deformation Radius at $35^{\circ} \mathrm{N}$ is close to the width of the Curtis Sea (Fig. 6; Zuchuat et al., 2019b). The tides propagated in a rectilinear fashion along the long-axis of the Curtis Sea, which is confirmed by palaeocurrent observations from the Curtis Formation (Fig. 7c; 9), and high tide and low tide, as well as ebb tide and flood tide have a very similar magnitude with the opposite direction. 
Time t (high tide in Curtis Sea)

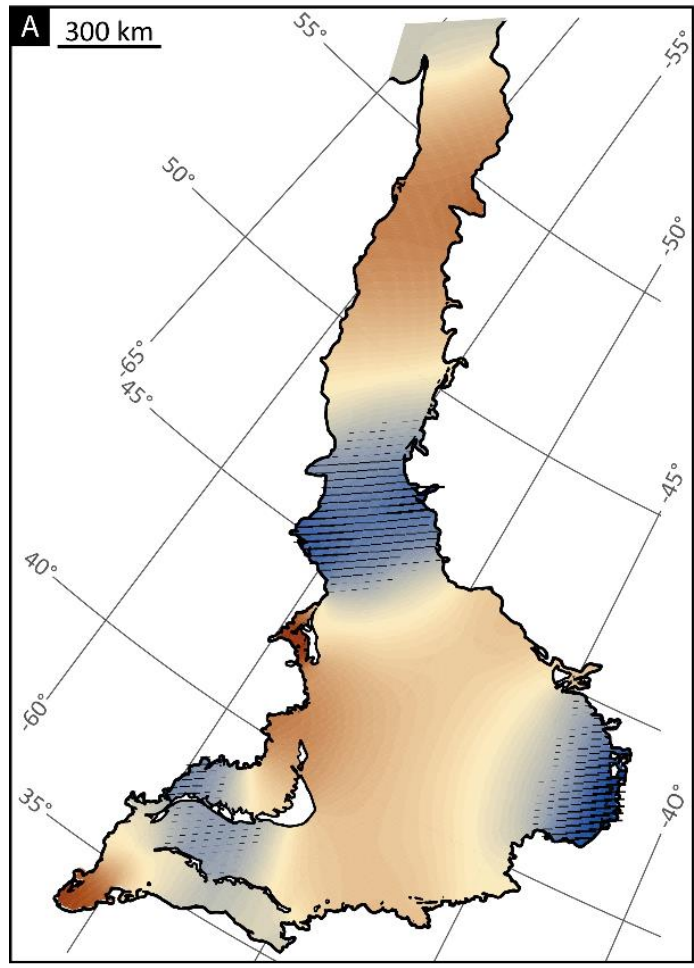

Time $t+6 \mathrm{~h}$ (low tide in Curtis Sea)

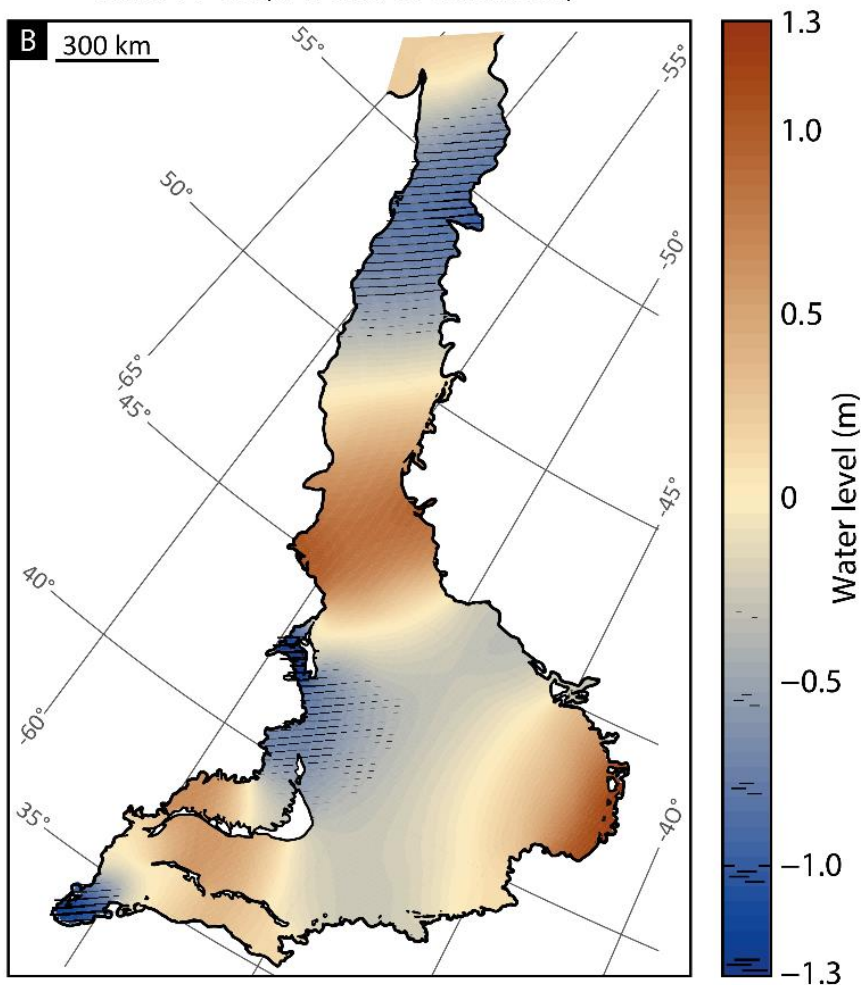

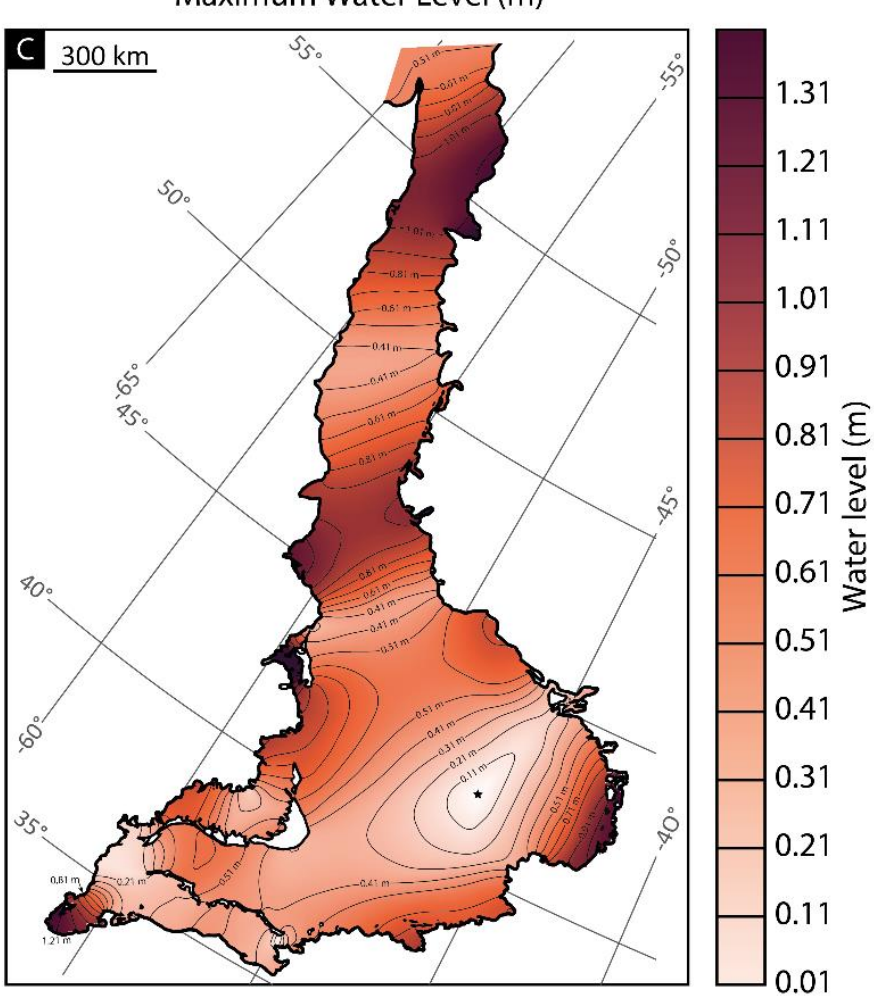

Fig. 6 - Maps showing the distribution of the water level at time $t$, corresponding to A) the high tide in the Curtis Sea, and B) at time $t+6$, corresponding to the low tide in the Curtis Sea, for the $600 \mathrm{~m} \mathrm{PPC}$, with an initial open-ocean tidal forcing of 0.5 $m$. C) Map showing the distribution of maximum water level $(m)$.

The tides at both the Curtis Sea coastline and the eastern margin of the Sundance Sea (EMSS) were characterised by an amplitude that is more than twice that of the tidal forcing at the mouth (Fig. 4, 6), but they were out of phase: when one region experienced high tides, low tides occurred in the other (Fig. 6A-B). Although the tidal amplitudes simulated in both areas were similar (Fig. 6C), differences occurred in maximum flow speed and bed shear stress values during their respective ebb and flood 
tides (Fig. 7a, 7b). Both of these values were much higher in the bottleneck of the Curtis Sea (Stove Gulch East, SGE; Fig. 7a, 7b, 8) than on the more open EMSS, indicating that the funnelling of the basin had a stronger impact on the simulated flow speed and the bed shear stress values than on the tidal amplitude. These results also indicate that most of the sediment transport in the Curtis Sea would occur during ebb tide and flood tides. These spatial variations in flow speed and bed shear stress would be reflected in the rock record, characterised by different sediment grain sizes (Yalin \& Karahan, 1979; van Rijn, 1993; Ward et al., 2015; 2020) and different sedimentary architecture (Hori et al., 2002; Costas et al., 2011, Sleveland et al., 2020) despite the similar tidal amplitudes.

A. Time $t$ (high tide in Curtis Sea)

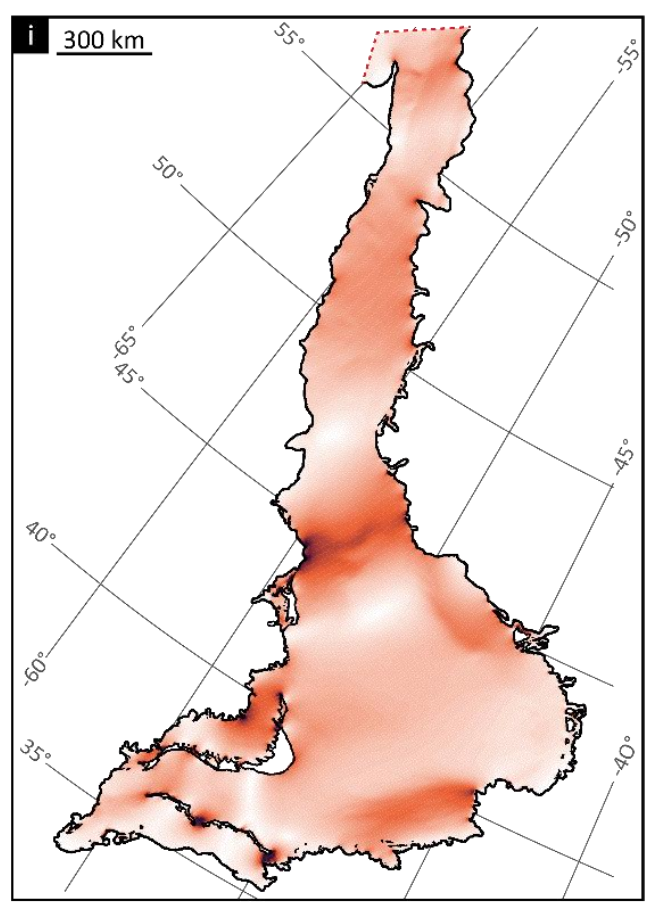

B. Timet (high tide in Curtis Sea) Time $\mathrm{t}+6 \mathrm{~h}$ (low tide in Curtis Sea)

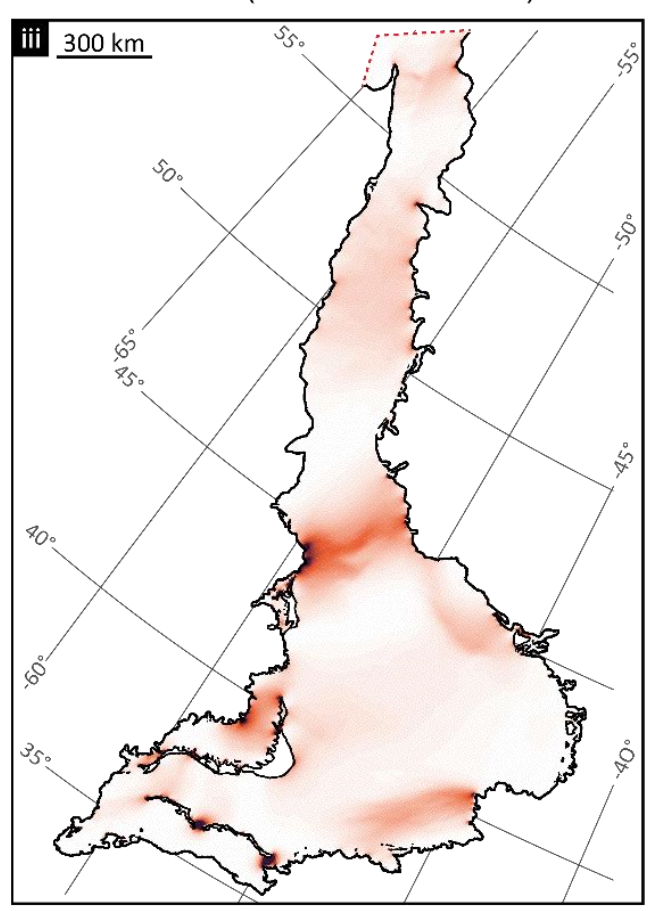

Time $\mathrm{t}+3 \mathrm{~h}$ (ebb tide in Curtis Sea)

Time $t+9 \mathrm{~h}$ (flood tide in Curtis Sea)

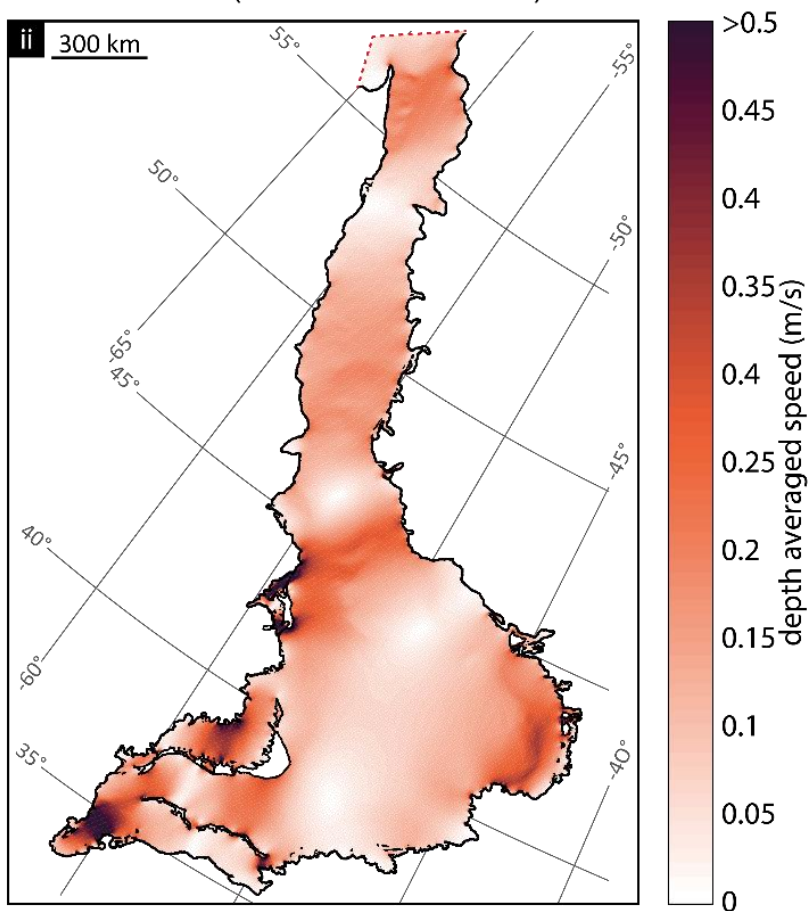

Time $\mathrm{t}+3 \mathrm{~h}$ (ebb tide in Curtis Sea)

Time $\mathrm{t}+9 \mathrm{~h}$ (flood tide in Curtis Sea)

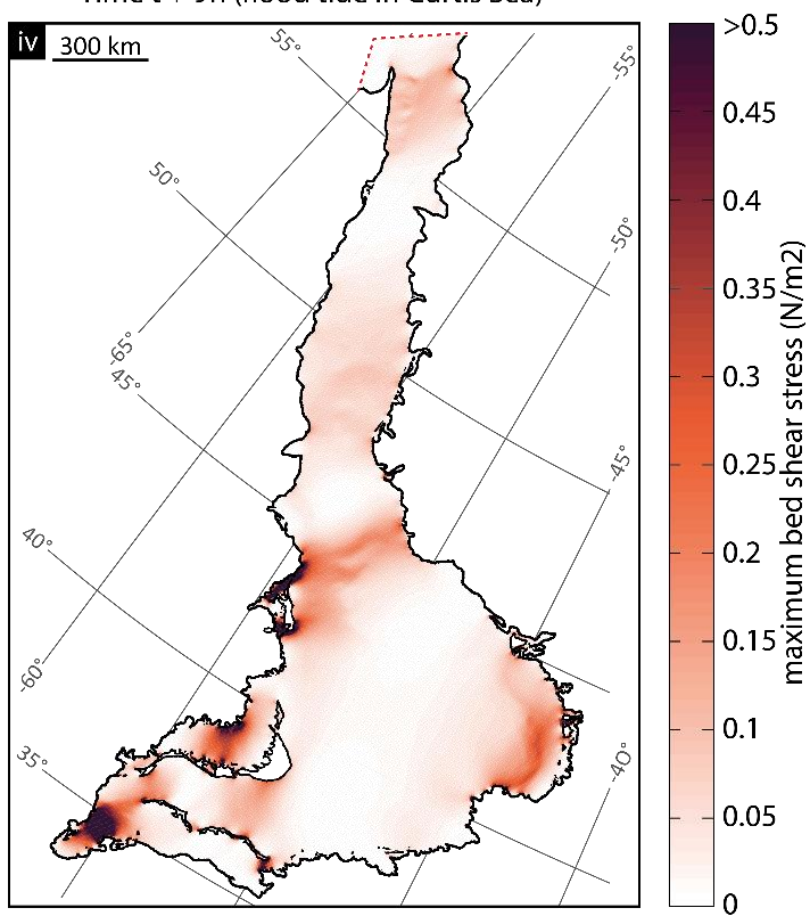


C. Time $\mathrm{t}+3 \mathrm{~h}$ (ebb tide in Curtis Sea)

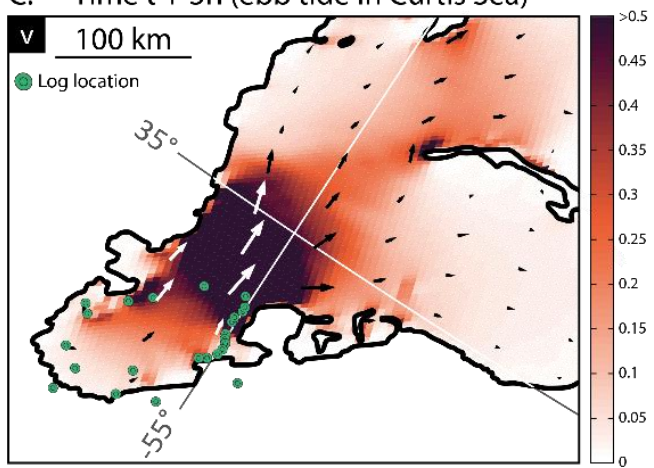

Time $\mathrm{t}+3 \mathrm{~h}$ (ebb tide in Curtis Sea)

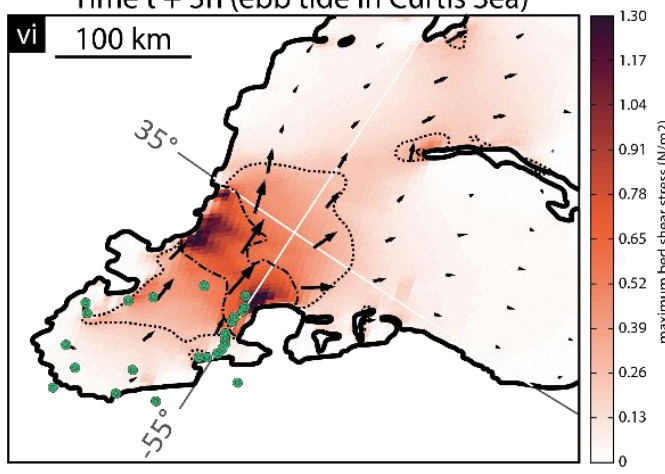

\begin{tabular}{|ll|}
\hline $\begin{array}{l}\text { Peak simulated } \\
\text { bed shear stress }\left(\mathrm{N} / \mathrm{m}^{2}\right)\end{array}$ & Expected sediments* \\
$<0,25$ & $\leq$ very fine sand \\
$0.25-0.6$ & fine sand \\
$0.6-3.2$ & $\geq$ medium sand \\
\hline
\end{tabular}

Fig. 7 -Simulation results for the $600 \mathrm{~m}$ PPC. A) Maps showing the distribution of the simulated depth-averaged speeds i) at time $t$ and $t+6$ (high tide and low tide in the Curtis Sea, respectively), and ii) at time $t+3$ and $t+9$ (ebb tide and flood tide in the Curtis Sea, respectively). High tide and low tide were grouped together because they have a very similar magnitude with the opposite direction, and ebb tide and flood tide have been grouped together for the same reason. B) Maps showing the distribution of the simulated bed shear stress values iii) at time tand $t+6$ (high tide and low tide in the Curtis Sea, respectively), and iv) at time $t+3$ and $t+9$ (ebb tide and flood tide in the Curtis Sea, respectively). C) Zoomed-in view of the Curtis Sea, showing $v$-vi) the distribution of the simulated bed shear stress values using two different scales at time $t+3$ (ebb tide in the Curtis Sea) with vector arrows, as well as the locations of sedimentary logs displayed in Fig. 9. Expected sediments modified after Ward et al. (2015).

The wavelength $L$ of the tidal wave (Sztanó and de Boer, 1995; Allen, 1997) in the innermost part of the Curtis Sea is $\sim 900 \mathrm{~km}$ (Fig. 6, from the edge of the Curtis Sea towards the Sundance Sea). Using the equation:

$$
L=T \sqrt{g d}
$$

with $T$ being the $M 2$ periodicity $(44,712 \mathrm{~s}), g$ the gravitational acceleration $\left(9.81 \mathrm{~ms}^{-2}\right)$, and $d$ the average water depth we can solve for the depth $d$ that indicates

when the Curtis Sea will reach M2 resonance. This happens when the average water depth $d$ is ca. 41 $\mathrm{m}$. It is difficult to assess the validity of this calculation given the variability of the palaeobathymetry, but it does appear to fit the average depth of the Curtis Sea for the $600 \mathrm{~m}$ PPC (Fig. 1, 8).

Further, knowing $L$ and using Equation (4), resonances could have developed in the Curtis Sea when the basin reached a length of ca. $225 \mathrm{~km}(\mathrm{~L} / 4), 675 \mathrm{~km}(3 \mathrm{~L} / 4)$, or $1125 \mathrm{~km}(5 \mathrm{~L} / 4)$. A length of $675 \mathrm{~km}$ approximately corresponds the distance between the entrance of the Curtis Sea and its innermost part, while a length of $1125 \mathrm{~km}$ approximately corresponds to distance between the centre of the Sundance Sea and the innermost part of the Curtis Sea (Fig. 6).

\section{Change in palaeophysiographic configuration}

Changes in PPC strongly affected the resulting simulated tidal amplitude, and hence the flow speed and associated bed shear stress in the basin (Fig. 8). Certain PPCs resulted in an overall amplification of the initial tidal signal (e.g. $555 \mathrm{~m}, 600 \mathrm{~m}$, and $645 \mathrm{~m}$ depth scenarios), whereas other PPCs caused these parameters to be dampened ( $300 \mathrm{~m}, 820 \mathrm{~m}$, and $1430 \mathrm{~m}$ depth scenarios), or ever so slightly amplified for only a few localities (460 m, and $1200 \mathrm{~m}$ depth scenarios). Nevertheless, the reactivity of the system to change in PPC was not uniform across the basin. The observation sites located in the central and deeper areas of the basin (Middle Sundance Sea (MSS) and Middle Curtis Sea (MCS)) recorded a more dampened tidal amplitude with respect to the initial tidal forcing in all simulations, 
and their response to change in PPC was less-pronounced than observation sites located closer to the shoreline. For instance, the coastal site at Sid and Charley (Fig. 1, SaC), showed strong changes in response to changing PPC. At Sid and Charley, tides were barely amplified with respect to the initial $0.5 \mathrm{~m}$ tidal forcing under the $460 \mathrm{~m}$ depth scenario, reaching tidal amplitude values $0.56 \mathrm{~m}$ (Fig. 8; see also Appendix B). However, under the $600 \mathrm{~m}$ depth scenario, which resulted in a local increase in water depth of only $\sim 6 \mathrm{~m}$, tides were amplified to $1.28 \mathrm{~m}$. Not all coastal areas responded to change in PPC in a similar manner, illustrated by the results of the $1000 \mathrm{~m}$ depth scenario (Fig. 8). This PPC led to spatial separation of the tidal amplification in the basin: the tidal amplitude at the eastern margin of the Sundance Sea (EMSS) was nearly twice the value of the initial tidal forcing, whereas the tidal amplitude in the Curtis Sea was reduced to nearly half the value of the initial tidal forcing. Despite an increased tidal amplitude, the $1000 \mathrm{~m}$ depth scenario did not lead to increased flow speed and associated bed shear stress values at the EMSS. Consequently, changes in PPC controlled both the magnitude and the location of tidal amplification, as well as flow speed and bed shear stress variations in the basin. This shows the importance of physiography on regional tidal dynamics and further supports the large-scale results of Blackledge et al (2020), who showed that tidal dissipation rates are fundamentally controlled by the distribution of continental masses and associated ocean bathymetry around the globe, and the tidal dissipation rates will vary through geological time as a consequence of plate tectonics (e.g., Green et al., 2018).

The results of these simulations suggest how the system would respond to relative sea-level variations, using the steps between each depth scenario as a proxy for relative sea-level change (Fig. 8). Starting with the shallowest basin configuration (i.e., the $300 \mathrm{~m}$ depth scenario), tides first become amplified as the relative sea level increases, until the system reaches an ideal PPC (the $600 \mathrm{~m}$ depth scenario), for which the tidal amplitudes are at a maximum, especially in shallow areas close to the coastline. As relative sea level rise continues, the tidal amplitude subsequently diminishes everywhere in the basin. The deeper the basin becomes, the more heterogeneous the spatial distribution of the tidal amplitude is, resulting in different periodic resurgence of tidal amplification or dampening (Fig. 8). As a result, the hydrodynamics and resulting sedimentary deposits would strongly vary from one side of the basin to the other, despite a similar relative sea-level history. 

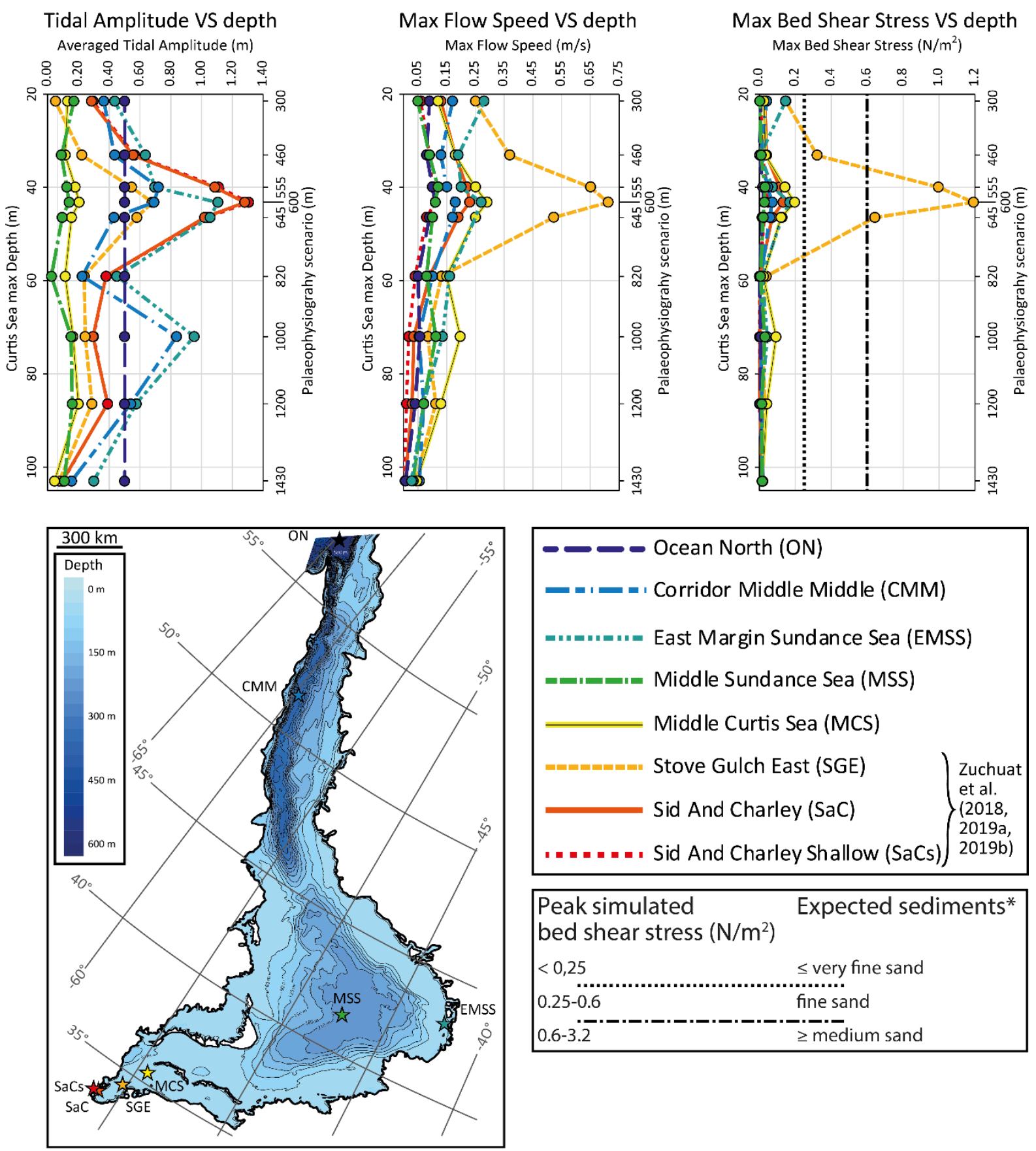

\begin{tabular}{|c|c|}
\hline $\begin{array}{l}\text { Peak simulated } \\
\text { bed shear stress }\left(\mathrm{N} / \mathrm{m}^{2}\right)\end{array}$ & Expected sediments* \\
\hline$<0,25$ & $\leq$ very fine sand \\
\hline $0.25-0.6$ & fine sand \\
\hline $0.6-3 . \overline{2}$ & $\geq$ medium sand \\
\hline
\end{tabular}

Fig. 8 - Simulated maximum tidal amplitudes, flow velocities, and bed shear stress at 8 key localities, for each modelled palaeophysiography-scenario, with an initial open-ocean tidal forcing of $0.5 \mathrm{~m}$ at the mouth of the system (ON). Expected sediments modified after Ward et al. (2015).

\section{Change of initial tidal forcing}

Figure 5 summarizes the effects of varying the tidal forcing at the open boundary from $0.5 \mathrm{~m}$ to $2 \mathrm{~m}$, illustrated by data from SaCs and EMSS (Fig. 1; see Appendix B). The simulations were sensitive to changes in initial tidal forcing, but each location reacted differently to these variations, as illustrated by the various increase factors. Under a $555 \mathrm{~m}$ depth scenario, an initial tidal forcing of $0.5 \mathrm{~m}$ resulted in $122 \%$ amplification of the tides at SaCs, whereas initial forcing of $2 \mathrm{~m}$ resulted in $6.2 \%$ dampening of tides (Fig. 5). This means that, under a $555 \mathrm{~m}$ depth scenario, the amount of amplification at SaCs increased by a factor of 0.42 when augmenting the initial tidal forcing from $0.5 \mathrm{~m}$ to $2 \mathrm{~m}$. Contrastingly, at EMSS, this increase factor equalled 0.58. In other words, the tidal amplitude at both locations 
diminished, but it diminished differently when changing the initial tidal forcing from $0.5 \mathrm{~m}$ to $2 \mathrm{~m}$. Furthermore, the values of these increase factors changed non-linearly when running the simulations with a different PPC, and each locality followed a different, non-linear trend (Fig. 5).

The evolution of the relationship between the tidal amplitude and the flow speed with respect to changes in PPC is complex (Fig. 5) and requires incorporation of additional factors which go beyond the scope of this study to fully decipher the true link between the tidal amplitude and the associated flow speed. At SaCs, when using an initial tidal forcing of $0.5 \mathrm{~m}$, both $1000 \mathrm{~m}$ and $300 \mathrm{~m}$ depth scenarios experienced a similar tidal amplitude. However, the associated flow speed was three times higher for the $300 \mathrm{~m}$ depth scenario than it was for the $1000 \mathrm{~m}$ one. This discrepancy in flow speed was due to the different cross-sectional area of the basin between the depth scenarios: in both simulations, the same volume of water had to flow in the same amount of time. The simulated flow speed experienced using the $300 \mathrm{~m}$ PPC was three times higher than one experienced using the 1000 m PPC because the cross-sectional area was three times smaller.

\section{Dissipation rate, $D$}

Table 1 illustrates how the dissipation rate, $D$, may likely have evolved in the Curtis Sea as a function of initial tidal forcing and PPC. Overall, an increase in initial tidal forcing always resulted in a higher rate of dissipation in the Curtis Sea, regardless of the PPC, because $D$ was calculated using Equation (3). Because the use of different PPC impacted the flow speed at each location (Appendix B), the resulting $D$-value of the Curtis Sea varied between simulations. Furthermore, since these changes in speed varied in a non-linear fashion as cross-sectional dimension varied, but not the volume of water to be moved (Fig. 5; see also Appendix B), the changes in dissipation rate $D$ evolved non-systematically as the PPC changed.

\section{Change in drag coefficient}

Changing the drag coefficient parameter, $C d$, impacted the modelled tidal amplitude, flow speed, and bed shear stress values (Appendix $\mathrm{C}$ ): lower $C d$ resulted in higher tidal amplitude and higher flow speeds. This relationship was not observed in the bed shear stress, which followed three different trends because of its interdependence on $C d$ and the speed (3). As $C d$ increases, the bed shear stress either (i) increases, (ii) increases then decreases, or (iii) decreases. These three trends were distributed systematically across the basin: the increasing trend was recorded from the mouth of the system into the main body of the Sundance Sea, whereas the increase-decrease and the decrease trends only occurred in the Curtis Sea.

\section{Model validation and implication for regional palaeogeography}

The lowermost interval of the shallow-marine Curtis Formation (lower Curtis, sensu Zuchuat et al., 2018) in east-central Utah is characterised by coarser sediments and more sand-dominated strata in the NE and the NW areas, whereas regions to the south generally display finer-grained, more thinly- 
bedded, and more heterolithic beds (Fig. 9, 10). This distribution of sedimentary facies and facies associations, when placed in a palaeogeographical context, shows that the coarser sediments were deposited near a bottleneck, towards the palaeo-connection between the Curtis and Sundance Seas and the NW-shoreline of the system, whereas finer sediments were deposited in the innermost parts of the Curtis Sea to the south.

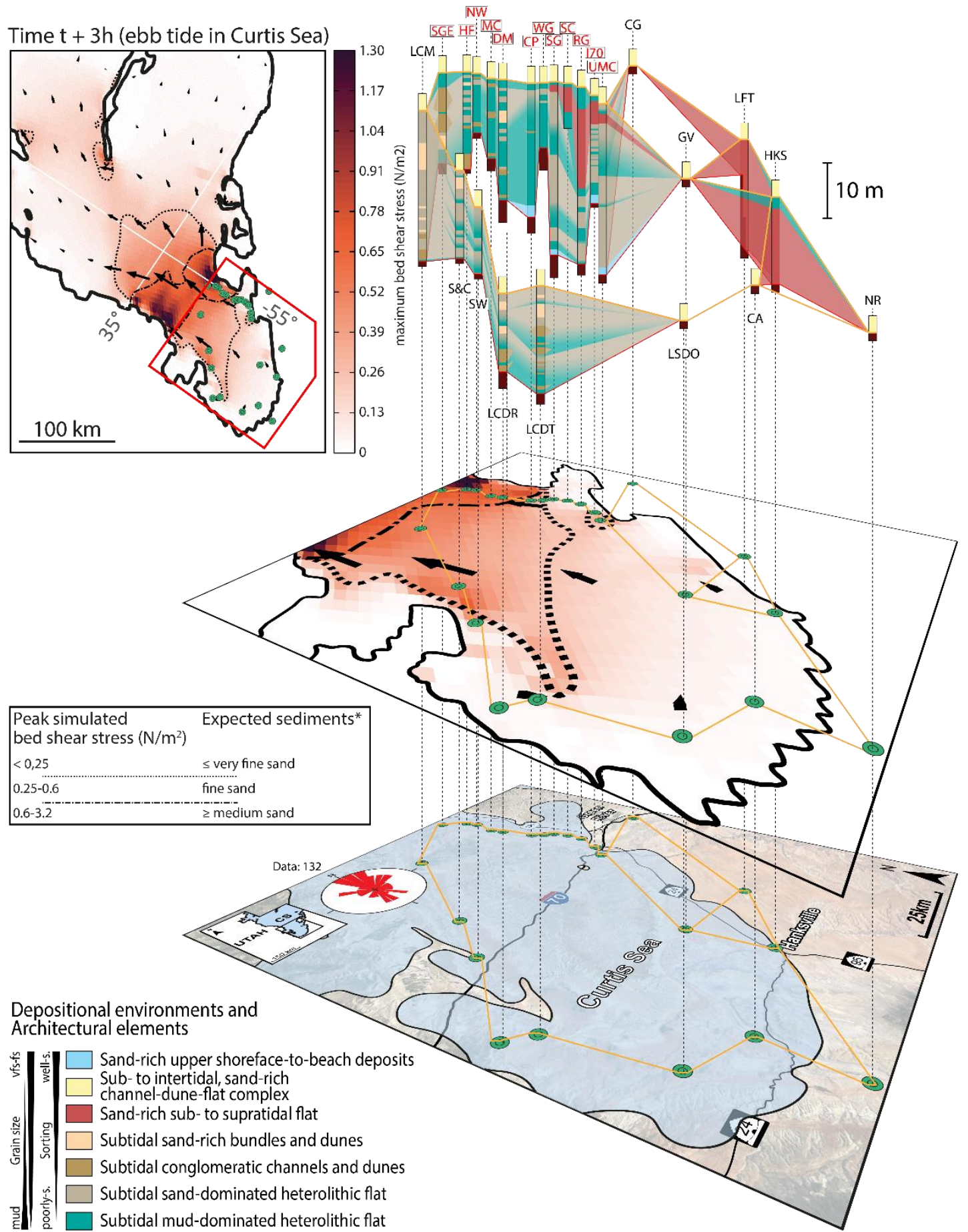

Fig. 9 - Fence diagram showing the distribution of the different facies associations and prominent architectural elements in the lower Curtis, draped onto the maximum-bed-shear-stress map at time $t+3$ (ebb tide in the Curtis Sea), and simplified palaeogeographical map of the Curtis Sea. The rose diagram indicates measured palaeocurrent direction in the lower Curtis. Location abbreviations, from the N, clockwise: SGE: Stove Gulch East; HF: Humbug Flats East; NW: Neversweat Wash; MC: Middle Canyon; DM: Dry Mesa; CP: Curtis Point; WG: Wet Gulch; SG: Sven's Gulch; SC: Smith's Cabin; RG: Rabbit Gulch; 170: Interstate 70; UMC: Uneva Mine Canyon; CG,: Crystal Geyser; GV: Goblin Valley; LFT: Little Flat Top; HKS: Hanksville; NR: Nottom Ranch; CA: Caineville Airstrip; LSDO: Lower South Desert Overlook; LSDT: Last Chance Desert Tower; LSDR: Last Chance Desert Road cut; SW: Saltwash View Area; SaC: Sid and Charley; LCM: Lower Cedar Mountain. Locations in red are displayed in a more detailed correlation panel in Fig. 10. Expected sediments after Ward et al. (2015). 
As an idealized approximation, simulated bed shear-stress values can be used as a proxy to estimate the different grain sizes of the sediments deposited by tidal processes (Ward et al., 2015, 2020), with higher bed shear stress corresponding to coarser sediments (Fig. 9). The distribution of the bed shearstress values in the Curtis Sea for the $600 \mathrm{~m} \mathrm{PPC} \mathrm{(Fig.} \mathrm{7c)} \mathrm{showed} \mathrm{a} \mathrm{very} \mathrm{similar} \mathrm{trend} \mathrm{in} \mathrm{comparison}$ to the observed grain-size distributions in the lower Curtis Formation, especially during ebb and flood tides. The highest bed shear stress values were concentrated near the bottleneck towards the palaeoconnection between the Curtis and Sundance Seas to the NE, as well as along the NW-shoreline of the system. The innermost parts of the Curtis Sea were characterised by lower bed shear-stress values, which corresponds well with finer-grained sediments observed in outcrop (Fig. 9, 10). It is worth noting that a better-resolved bathymetry will have an impact on the values and the distribution of the bed shear stress in the model, but the given the regional nature of the modelled tides and the physiography of the basin, the matching trends between the simulations and the rock record will most likely remain the same.

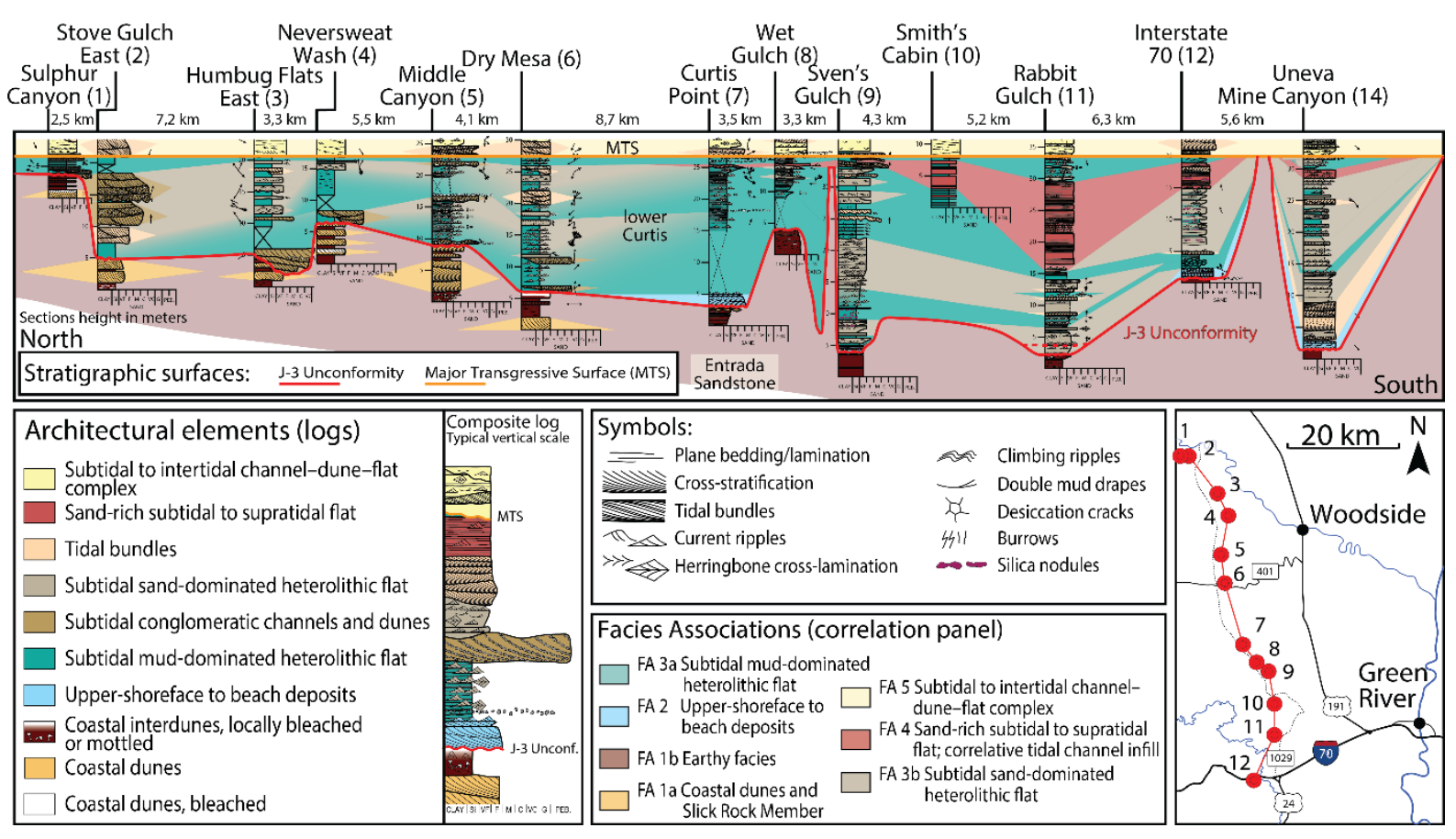

Fig. 10 - Correlation panel of the lower Curtis across the NE margin of the San Rafael Swell, showing the distribution of facies associations (see Zuchuat et al., 2018 for detailed sedimentological descriptions).

The model did not match all outcrop localities. Though the model could explain the sedimentary architecture of the lower Curtis Fm. in the northern and western parts of the study area, it failed to explain the southward-coarsening trend observed in outcrop towards the innermost parts of the Curtis Sea (Fig. 9, 10). The model predicted that the sediments in these southern areas could not be coarser than very fine sand (Fig. 7c, 9, 10), but the lower Curtis Fm. in these southern areas consists of mostly thinly-bedded fine-grained sandstones (Fig. 9, 10) with diagnostic tidal signatures (Kreisa \& Moila, 1986; Caputo \& Pryor 1991; Wilcox \& Curie, 2008; Zuchuat et al., 2018). Such discrepancies between the simulated sediment distribution and the geological record in the southern areas of the Curtis Sea could be an artefact of the model's simplicity, which only integrated the M2 tidal 
constituent, as well as a grid-resolution too big to render the effect of the precise coastal geometry and positive and negative features developing on the seafloor (dunes, bars, troughs, channels, etc.). Furthermore, variations in clay content and quantity of extracellular polymeric substances (Baas et al., 2019) would have impacted the nature and separation of the flow (Baas et al., 2019; Wang et al., 2019), as well as the distribution of sediment and bedforms in the system. Integrating these additional factors to the simulations, as well as increasing the grid resolution, might help to reduce the existing discrepancies between the model and the Curtis Formation, especially at a local scale (e.g. Azhikodan and Yokoyama, 2018). General trends, however, are expected to remain relatively constant, even with the addition of more complex input parameters.

Differences between the geology and the model could also suggest that sediment in the innermost parts of the Curtis Sea was transported and deposited by other processes (e.g. wind or flash floods; Anthony et al., 2010; Blanchard et al., 2016; Rivers et al., 2020), but whose signatures were not preserved in the rock record. Indeed, small relative sea-level changes in low-gradient basins lead to the migration of facies belts over large horizontal distances (Midtkandal \& Nystuen, 2009; van Yperen et al., 2019). The effects associated with the migration of the facies belts can be further amplified in arid, paralic environments, when these relative sea-level variations are associated with arid-humid climatic oscillations (Mountney, 2006; Anthony et al., 2010; Jordan \& Mountney, 2010, 2012; Blanchard et al., 2016; Vieira et al., 2017). Increased periods of aridity facilitate the deposition and progradation of sand flats and aeolian dunes, which can subsequently be reworked by tidal currents as the sea transgresses the previously-exposed coastal areas (Anthony \& Dobroniak, 2000; Anthony et al., 2010).

As absolute water-depth information is lacking for the Sundance and Curtis Seas, we propose that the $600 \mathrm{~m}$ PPC could be considered a realistic depiction of the basin configuration during the earliest Oxfordian when the lower Curtis was being deposited (sensu Zuchuat et al., 2018), based on the simulation results and the similarities between the modelled sedimentary proxies and the rock record. The Sundance Sea would have therefore reached a maximum depth of $\sim 240 \mathrm{~m}$, and the seafloor of the Curtis Sea would have laid 40-45 m below the surface. In this context, the $2.60 \mathrm{~m}$ tidal range of the Curtis Sea would classify it as a meso-tidal system.

\section{Discussion}

\section{Comparison to modern systems}

There are no modern analogues of the epicontinental Sundance and Curtis Seas in terms of both size and setting. However, the general physiography and hydrodynamics of the studied system resembles the Bay of Fundy and Ungava Bay in Canada, which both have elongated distributary valleys connected to bays in which 'rotating or residual currents' can develop (Archer, 2013, and references therein). The amplitude of the highest tides modelled in the Curtis Sea reach $1.30 \mathrm{~m}$, much less than the ones 
occurring in today's above-mentioned hypertidal systems(sensu Archer, 2013) in which the maximum tidal amplitude reaches 8.5 and $8.8 \mathrm{~m}$, respectively (Canadian Tide and Current Tables, 2021). These rotational currents generate a wave that propagates into the narrower distributary valleys, eventually leading to tidal amplification (Archer, 2013). This process is analogous to the tidal amplification observed in the modelled Curtis Sea (Fig. 6C). The Curtis Sea was much longer and wider than these modern hypertidal counterparts, and had a unique long corridor that connected the Sundance Sea to the open ocean, which could explain why the values of the simulated tidal amplitude are much lower in the Curtis Sea than in the Bay of Fundy or Leaf Lake.

\section{Impact on sequence stratigraphy of tide-dominated basins}

The spatial distribution of sedimentary facies in tide-dominated environments is usually characterised by the deposition of finer-grained sediments along the coastline and coarser sediments at greater water depth, where current velocities and associated bed shear stress are higher (Dalrymple et al., 2012; Fan, 2012). Fining-upwards sedimentary successions are therefore typically interpreted to record coastal progradation. However, this assumes that the tidal dynamics in the system remain constant, despite changes in the physiography of basin. This study highlights how changing sea-level can have a major impact on basin physiography and therefore tidal dynamics, which should be considered when interpreting tidal stratigraphy. To explore this further, a schematic sedimentary log is considered, with a lower coarsening-upward interval overlain by a fining-upward succession (Fig. 11; referred to as one CU2FU package). This hypothetical succession was deposited at SaCs in the Curtis Sea (Fig. 1). The lower CU-interval recorded a period of waxing energy, with increasing tidal amplitude, flow speed, and bed shear stress values, while the upper FU interval recorded a period of constant waning energy. Classic tidal facies models (Dalrymple et al., 2021; Fan, 2012) would interpret a waxing-to-waning energy trend as a transgression followed by regression, driven by either sea-level fluctuations or changes in sediment supply. Although variations in sediment supply would add an extra dimension to the complexity of the problem, we simplify this discussion by focusing on potential patterns driven solely by relative sea-level fluctuations. Results of the simulations presented in this study (Fig. 8) indicate that a coarsening-to-fining upward trend could reflect four different relative sea-level histories: (i) a relative sea-level rise-then-fall cycle (Fig. 11c; or a relative sea-level rise followed by a period of relative sea-level standstill associated with coastal progradation); (ii) a relative sea-level fall-then-rise cycle (Fig. 11d); (iii) a constant relative sea-level rise (Fig. 11a); (iv) or a constant relative sea-level fall (Fig. 11b). In these two latter cases, the coarsest sediments would have been deposited when the physiography of the basin reached an optimal configuration that maximized tidal amplification, flow speed, and associated bed shear stress, potentially even reflecting the development of a resonant stage. Consequently, such a sedimentary succession is non-unique (sensu Burgess \& Prince, 2015), because several different relative sea-level histories could produce the same 
pattern. Future work will help improve the understanding and the recognition of the transition from a non-resonant to a resonant stage in ancient, tide-dominated systems such as the Curtis Sea.

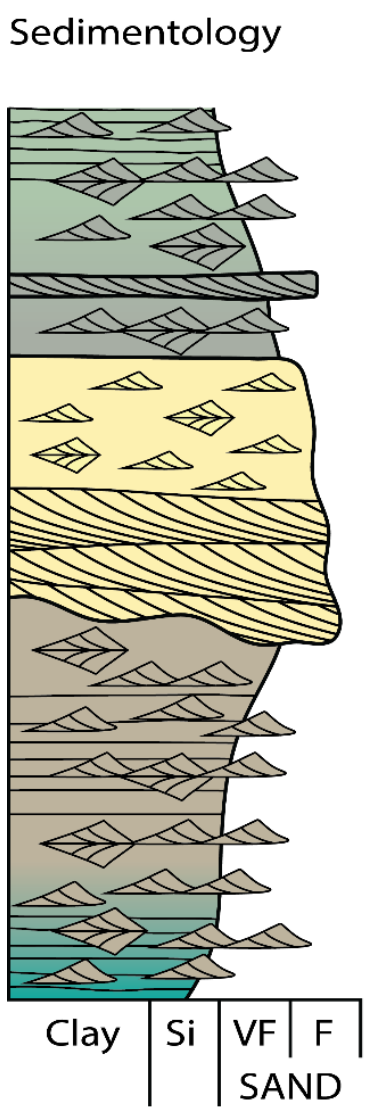

\section{Bed shear stress; speed; tidal ampli.}

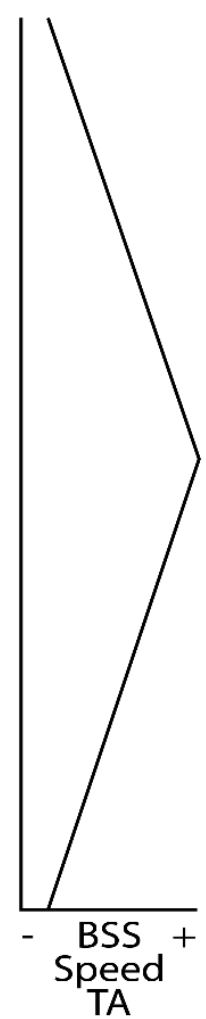

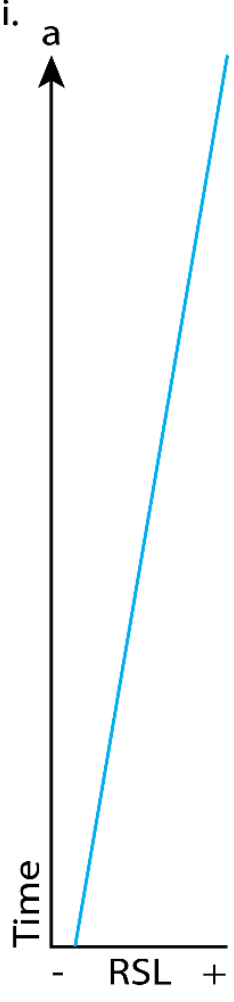

a) Constant RSL rise

b) Constant RSL fall

\section{Evolution scenarios}

b

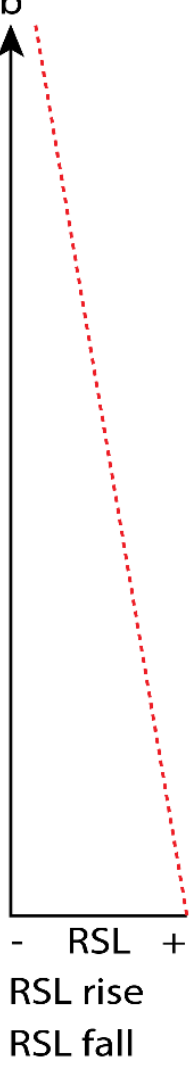

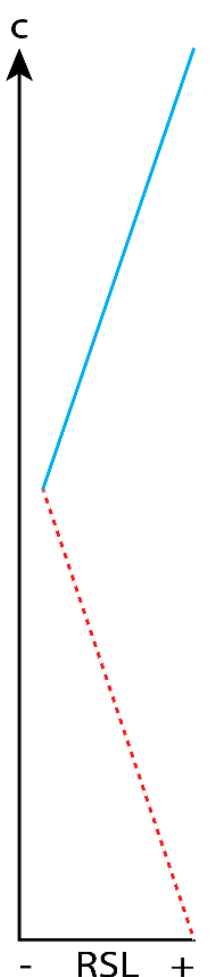

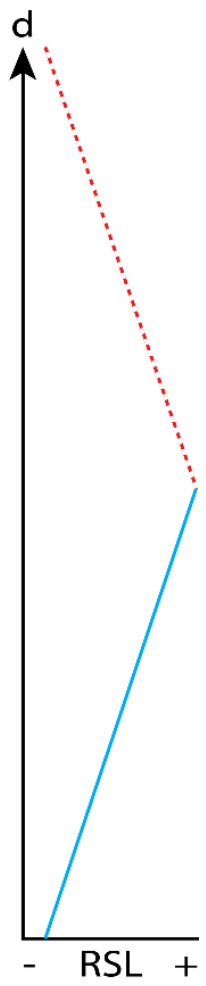

c) RSL fall, followed by RSL rise

d) RSL rise, followed by RSL fall

Fig. 11 - Schematic log of a hypothetical tide-dominated sedimentary succession from SaCs, showing a coarsening-upward trend, followed by a fining-upward trend. According to the simulation results, the sedimentology alone, in a tide dominated environment, does not reflect a specific relative sea-level (RSL) history. Four different RSL scenarios can lead to the same sedimentological column. BSS: bed shear stress; TA: tidal amplitude.

Considering the CU2FU trend of the schematic sedimentary section in Figure 10, and assuming that this succession was deposited under constant relative sea-level rise, this same constant relative sealevel rise would have resulted in the deposition of two CU2FU packages overlying each other in the EMSS (Fig. 1) at a similar depth because that part of the basin would have reached a resonance-prone configuration twice (Fig. 8). Note that such a hypothetical section from the EMSS could reflect up to 16 different relative sea-level histories. This exercise is non-trivial, because it illustrates the fact that in a basin in which tides are one of the dominant hydrodynamic processes, one particular relative sealevel history will result in the deposition of different sedimentary successions in different parts of the basin despite similar water depth, as they will reach a resonant-prone configuration at different moments in the basin's history. Consequently, in a tide-dominated basin, it is possible to consider relative sea-level change and its effect(s) as non-unique (sensu Burgess \& Prince, 2015).

Greenberg et al. (2012) and Arns et al. (2015) showed that even a minor increase in relative sea level leads to a non-linear change in tidal amplitude combined with an altered tidal energy dissipation, 
especially in coastal areas close to tidal resonance. But these changes are expressed differently depending on how the local physiography, the associated dissipation of tidal energy, and resonance properties of the basin evolve with respect to relative sea level fluctuations (e.g. Ward et al., 2012; Pelling et al., 2013; Carless et al., 2016; Idier et al., 2017). The simulation results confirm that the Sundance and the Curtis Seas would have experienced the same spatial-dependence of tidal processes variations with respect to relative sea-level change (Fig. 8). Thus, it is essential to consider distinct interpretations when investigating the evolution of a palaeo-sea in which tides were one of the main process influencing the distribution and the deposition of sediments. The interpretation of the relative sea-level and sediment influx variations recognised in the stratigraphy could be refined and strengthened by the integration of additional proxies, including, among others, ichnology, clay mineralogy, and/or the analysis of bedform dynamics.

\section{Conclusions}

Recent research on modern tidal environments highlights the complexity of tidal systems (Gugluitta et al., 2017; Cosma et al., 2020; Finotello et al., 2020). This increased understanding of modern systems is one way to improve the recognition and the interpretation of ancient tides (see discussion in Gugliotta and Saito, 2019). In addition to including insight from modern environments, numerical modelling (e.g. Collins et al., 2018) can help to test hypotheses formulated from the study of the rock record and to tune ancient tidal signals to astronomic parameters, which have changed through time (Green et al., 2017, 2018; Davies et al., 2020).

The use of numerical modelling of the Upper Jurassic Sundance and Curtis Seas allowed for constraints on and quantification of some of the tidal characteristics observed in the Upper Jurassic Curtis Formation (e.g. Kreisa \& Moila, 1986; Caputo \& Pryor 1991; Wilcox \& Curie, 2008; Doelling et al., 2013; Zuchuat et al., 2018; 2019a; 2019b), as well as documentation of the influence of varying PPC, initial tidal forcing, and bed shear stress values on the behaviour of $M 2$ tides across epicontinental seas.

In the present study, the tidal simulations showed that changes in PPC controlled the magnitude and the location of tidal amplification, flow speed, and bed shear stress variations in the basin. These variables were also impacted by changes in initial tidal forcing and bottom drag coefficient, though to a lesser extent than changes in PPC.

Simulation results obtained using the $600 \mathrm{~m}$ depth scenario predicted a distribution of sedimentary facies similar to the one observed in the lower Curtis Formation, except in the southernmost parts of the Curtis Sea, close to the palaeoshoreline, where sediments might have been transported from the neighbouring arid coastal plain by aeolian processes and subsequently reworked by tidal currents during a later transgression. The $600 \mathrm{~m}$ depth scenario can therefore be considered a realistic PPC for the Sundance and Curtis Seas. In this case, the Sundance Sea would have reached a maximum depth of $\sim 240 \mathrm{~m}$, and the seafloor of the Curtis Sea would have reached maximum depth of 40-45 m. In this 
context, the simulated $2.60 \mathrm{~m}$ tidal range of the Curtis Sea would classify it as a meso-tidal system ( $2 \mathrm{x}$ $1.30 \mathrm{~m}$ tidal amplitude).

Finally, sedimentary successions deposited in tide-dominated basins reflect the energy level and the degree of tidal amplification (or dampening) that prevailed at the time of deposition. Because these energy variations can be the product of several, equally-valid relative sea-level variations leading to the onset and cessation of tidal resonance, the resulting sedimentary successions could be considered non-unique (sensu Burgess \& Prince, 2015). We also find that a given relative sea-level curve can lead to distinctive stacking patterns in different parts of a basin because of local appearance of additional tidal harmonics, implying that relative sea-level changes are also non-unique. Consequently, caution is required, and several possible interpretations should be considered when developing a geological model of a palaeo-sea, especially if tides were a predominant process at the time of deposition of the sediments. Additional proxies should be considered to robustly interpret the true relative sea-level variations recorded within tide-dominated basins, including, among others, ichnology, clay mineralogy, and/or the analysis of bedform dynamics.

This work highlights the necessity to consider the effects of PPC changes related to relative sea-level variations and their associated impact on tidal dynamics, which will improve and refining models of tide-dominated basins and their evolution. This increased knowledge of past basins will help to advance the comprehension of how tidal processes will evolve in response to ongoing sea-level rise.

\section{Acknowledgments}

The authors of this paper thank the Norwegian Research Council for their awarded Personal Overseas Research Grant (ref. Number 295061), which allowed the main author to attend Queen's University in Kingston, Canada, as a visiting scholar for 6 months. The Norwegian Research Council is to be further acknowledged for its COTEC grant (ref. Number 295061). Dr. Alexander Rey at Queen's University is recognised for help setting up Delft3D model. JAMG acknowledges funding from the UK Natural Environment Research Council, grant NE/S009566/1 (MATCH). The authors thank Dr Hannah Louise Brooks for her fruitful comments on parts of the manuscripts and its figures, David Hadley-Pryce for his insight on tidal forcing, and Dr Miquel Poyatos-Moré and Dr Anna van Yperen for discussing the impacts that these changes of PPC can have on the sequence stratigraphy of tide-dominated basins with me. Dr Luc Girod is also sincerely thanked, because without him, the first author of this manuscript would probably still be trying to fix his Georaster package. The two reviewers Andrew La Croix and Martin Wells who worked on an earlier version of this manuscript are to be sincerely acknowledged for their constructive observations and remarks, as well as Poppe de Boer who commented on the preprint version of this manuscript. 


\section{Conflicts of interest}

There are no conflicts of interest in the preparation or publication of this work.

\section{Data Availability}

All the simulations results and other data presented in this paper $(>500 \mathrm{~Gb})$ can be saved on an external hard-drive and sent by postal mail.

\section{References}

Anderson, T.H. (2015). Jurassic (170-150 Ma) bathe tracks of a continental-scale fault, the MexicoAlaska megashear, from the Gulf of Mexico to Alaska. In Anderson, T.H., Didenko, A.N., Johnson, C.L., Khanchuk, A.I., \& MacDonald, J.H. (Eds.), Late Jurassic margin of Laurasia: a record of faulting accommodating plate rotation, Geological Society of America, Special Paper 513, 107-188.

Anderson, O.J., \& Lucas, S.G. (1994). Middle Jurassic stratigraphy, sedimentation and paleogeography in the southern Colorado Plateau and southern High Plains. In: Caputo, M.V., Peterson, J.A., \& Franczyk, K.J. (Eds.), Mesozoic Systems of the Rocky Mountain Region, USA, SEPM, Rocky Mountain Section, 299-314.

Anthony, E.J., \& Dobroniak, C. (2000). Erosion and recycling of aeolian dunes in a rapidly infilling macrotidal estuary: the Authie, Picardy, northern France. Geological Society, London, Special Publications, 175(1), 109-121.

Anthony, E.J., Mrani-Alaoui, M., \& Héquette, A. (2010). Shoreface sand supply and mid-to late Holocene aeolian dune formation on the storm-dominated macrotidal coast of the southern North Sea. Marine Geology, 276(1-4), 100-104.

Arns, A., Wahl, T., Dangendorf, S., \& Jensen, J. (2015). The impact of sea level rise on storm surge water levels in the northern part of the German Bight. Coastal Engineering, 96, 118-131.

Ashall, L.M., Mulligan, R.P., Van Proosdij, D., \& Poirier, E. (2016). Application and validation of a threedimensional hydrodynamic model of a macrotidal salt marsh. Coastal Engineering, 114, 35-46.

Azhikodan, G., \& Yokoyama, K. (2018). Sediment transport and fluid mud layer formation in the macrotidal Chikugo river estuary during a fortnightly tidal cycle. Estuarine, Coastal and Shelf Science, 202, 232-245.

Baas, J.H., Baker, M.L., Malarkey, J., Bass, S.J., Manning, A.J., Hope, J.A., ... \& Thorne, P.D. (2019). Integrating field and laboratory approaches for ripple development in mixed sand-clay-EPS. Sedimentology, 66(7), 2749-2768.

Bjerrum, C.J., \& Dorsey, R.J. (1995). Tectonic controls on deposition of Middle Jurassic strata in a retroarc foreland basin, Utah-Idaho trough, western interior, United States. Tectonics, 14(4), 962-978.

Blackledge, B.W., Green, J.A.M., Barnes, R., \& Way, M.J. (2020). Tides on Other Earths: Implications for Exoplanet and Palaeo-Tidal Simulations. Geophysical Research Letters, 47(12), e2019GL085746.

Blakey, R.C. (2014). Paleogeography and paleotectonics of the western interior seaway, JurassicCretaceous of North America. Search and Discovery, 30392, 72. 
Blanchard, S., Fielding, C.R., Frank, T.D., \& Barrick, J.E. (2016). Sequence stratigraphic framework for mixed aeolian, peritidal and marine environments: Insights from the Pennsylvanian subtropical record of Western Pangaea. Sedimentology, 63(7), 1929-1970.

Brenner, R.L., \& Peterson, J.A. (1994). Jurassic sedimentary history of the northern portion of the Western Interior Seaway, USA. In: Caputo, M.V., Peterson, J.A., \& Franczyk, K.J. (Eds.), Mesozoic Systems of the Rocky Mountain Region, USA, SEPM, Rocky Mountain Section, 233-272.

Brown, M.M., Mulligan, R.P., \& Miller, R.L. (2014). Modeling the transport of freshwater and dissolved organic carbon in the Neuse River Estuary, NC, USA following Hurricane Irene (2011). Estuarine, Coastal and Shelf Science, 139, 148-158.

Burgess, P.M., \& Prince, G.D. (2015). Non-unique stratal geometries: implications for sequence stratigraphic interpretations. Basin Research, 27(3), 351-365.

Byrne, H.M., Green, J.A.M., Balbus, S.A., \& Ahlberg, P.E. (2020). A key environmental driver of osteichthyan evolution and the fish-tetrapod transition? Proceedings of the Royal Society $A$, 476(2242), 20200355.

Caputo M.V., \& Pryor W.A. (1991). Middle Jurassic tide- and wave-influenced coastal facies and paleogeography, upper San Rafael Group, east-central Utah. In: T.C. Chidsey (Ed.), Geology of EastCentral Utah, Utah Geological Association, Salt Lake City, 9-27.

Carless, S.J., Green, J.A.M., Pelling, H.E., \& Wilmes, S.B. (2016). Effects of future sea-level rise on tidal processes on the Patagonian Shelf. Journal of Marine Systems, 163, 113-124.

Carr-Crabaugh, M., \& Kocurek, G. (1998). Continental sequence stratigraphy of a wet eolian system: a key to relative sea-level change. In: Stanley, K.W., and McCabe, P.J. (Eds.), Relative Role of Eustasy, Climate, and Tectonics in Continental Rocks, SEPM, Special Publication 59, 213-228.

Cartwright, D. (2001). On the origins of knowledge of the sea tides from antiquity to the Thirteenth Century. Earth sciences history, 20(2), 105-126.

Collins, D.S., Avdis, A., Allison, P.A., Johnson, H.D., Hill, J., \& Piggott, M.D. (2018). Controls on tidal sedimentation and preservation: Insights from numerical tidal modelling in the Late OligoceneMiocene South China Sea, Southeast Asia. Sedimentology, 65(7), 2468-2505.

Collins, D.S., Johnson, H.D., \& Baldwin, C.T. (2020). Architecture and preservation in the fluvial to marine transition zone of a mixed-process humid-tropical delta: Middle Miocene Lambir Formation, Baram Delta Province, north-west Borneo. Sedimentology, 67(1), 1-46.

Collins, D., Avdis, A., Wells, M.R., Mitchell, A.J., Allison, P.A., Johnson, H.D., Hampson, G.J., Hill, J., Dean, C.D., \& Piggott, M. (submitted). Predicting shoreline depositional process regimes using insights from palaeotidal modelling. Earth Science Reviews. 10.31219/osf.io/3pzv5

Cosma, M., Finotello, A., lelpi, A., Ventra, D., Oms, O., D'Alpaos, A., \& Ghinassi, M. (2020). Piracycontrolled geometry of tide-dominated point bars: Combined evidence from ancient sedimentary successions and modern channel networks. Geomorphology, 370, 107402.

Costas, S., \& FitzGerald, D. (2011). Sedimentary architecture of a spit-end (Salisbury Beach, Massachusetts): The imprints of sea-level rise and inlet dynamics. Marine Geology, 284(1-4), 203-216.

Crabaugh, M., \& Kocurek, G. (1993). Entrada Sandstone: an example of a wet aeolian system. In: Pye, K. (Ed.), The Dynamics and Environmental Context of Aeolian Sedimentary Systems, Geological Society of London, Special Publication, 72, 103-126. 
Dalrymple, R.W., Duncan, A.M., Ichaso, A.A., \& Choi, K.S. (2012). Processes, Morphodynamics, and Facies of Tide-Dominated Estuaries. In: In: Davis, R.A.,Jr., \& Dalrymple, R.W. (Eds.), Principles of tidal sedimentology, Dordrecht, Netherlands, Springer Science and Business Media, 187-229.

Danise, S., \& Holland, S.M. (2017). Faunal response to sea-level and climate change in a short-lived seaway: Jurassic of the Western Interior, USA. Palaeontology, 60(2), 213-232.

Danise, S., \& Holland, S.M. (2018). A sequence stratigraphic framework for the Middle to Late Jurassic of the Sundance Seaway, Wyoming: implications for correlation, basin evolution, and climate change. The Journal of Geology, 126(4), 371-405.

Danise, S., Price, G.D., Alberti, M., \& Holland, S.M. (2020). Isotopic evidence for partial geochemical decoupling between a Jurassic epicontinental sea and the open ocean. Gondwana Research, 82, 97107.

Darwin, G.H. (1898). The tides and kindred phenomena in the solar system: The substance of lectures delivered in 1897 at the Lowell institute, Boston, Massachusetts. Boston: Houghton, Mifflin and company.

Davies, H. S., Green, J.A., \& Duarte, J.C. (2020). Back to the future II: tidal evolution of four supercontinent scenarios. Earth System Dynamics, 11(1), 291-299.

Davis, R.A.,Jr., \& Dalrymple, R.W. (Eds.). (2012). Principles of tidal sedimentology, Dordrecht, Netherlands, Springer Science and Business Media, 661 pp.

Dean, C.D., Collins, D.S., van Cappelle, M., Avdis, A., \& Hampson, G.J. (2019). Regional-scale paleobathymetry controlled location, but not magnitude, of tidal dynamics in the Late Cretaceous Western Interior Seaway, USA. Geology, 47(11), 1083-1087.

Demko, T.M., Currie, B.S., \& Nicoll, K.A. (2004). Regional paleoclimatic and stratigraphic implications of paleosols and fluvial/overbank architecture in the Morrison Formation (Upper Jurassic), Western Interior, USA. Sedimentary Geology, 167(3-4), 115-135.

De Raaf, J.F. M., \& Boersma, J.R. (2007). Tidal deposits and their sedimentary structures (seven examples from Western Europe). Netherlands Journal of Geosciences/Geologie en Mijnbouw, 50(3), 479-504.

Doelling, H.H., Sprinkel, D.A., Kowallis, B.J., \& Kuehne, P.A. (2013). Temple Cap and Carmel Formations in the Henry Mountains Basin, Wayne and Garfield Counties, Utah. The San Rafael Swell and Henry Mountains Basin-geologic centerpiece of Utah: Utah Geological Association Publication, 42, 279-318.

Elias, E.P.L., Gelfenbaum, G., and Van der Westhuysen, A.J. (2012), Validation of a coupled wave-flow model in a high-energy setting: The mouth of the Columbia River, J. Geophys. Res., 117, C09011.

Eriksson, K.A. (1977). Tidal deposits from the Archaean Moodies Group, Barberton Mountain Land, South Africa. Sedimentary Geology, 18(1-3), 257-281.

Fan, D. (2012). Open-coast tidal flats. In: Davis, R.A.,Jr., \& Dalrymple, R.W. (Eds.), Principles of tidal sedimentology, Dordrecht, Netherlands, Springer Science and Business Media, 187-229.

Fang, G., Kwok, Y.K., Yu, K., \& Zhu, Y. (1999). Numerical simulation of principal tidal constituents in the South China Sea, Gulf of Tonkin and Gulf of Thailand. Continental Shelf Research, 19(7), 845-869.

Finotello, A., D’Alpaos, A., Bogoni, M., Ghinassi, M., \& Lanzoni, S. (2020). Remotely-sensed planform morphologies reveal fluvial and tidal nature of meandering channels. Scientific reports, 10(1), 1-13.

Fritzen, M.R., Cagliari, J., Candido, M., \& Lavina, E.L.C. (2019). Tidal bar cyclicity record in the Lower Permian: The Rio Bonito Formation, Paraná Basin, southern Brazil. Sedimentary Geology, 381, 76-83. 
Gilluly, J., \& Reeside, J.B. Jr. (1928). Sedimentary rocks of the San Rafael Swell and some adjacent areas in eastern Utah. U.S. Geological Survey, Professional Paper 150-D, 61-110.

Green, J.A.M., Huber, M., Waltham, D., Buzan, J., \& Wells, M. (2017). Explicitly modelled deep-time tidal dissipation and its implication for Lunar history. Earth and Planetary Science Letters, 461, 46-53.

Green, J.A.M., Molloy, J.L., Davies, H.S., \& Duarte, J.C. (2018). Is there a tectonically driven Supertidal cycle?. Geophysical Research Letters, 45(8), 3568-3576.

Green, J.A.M., Davies, H.S., Duarte, J.C., Creveling, J.C., and Scotese, C. (2020). Weak tides during Cryogenian glaciations. Nature Communications, 11, 6227.

Greenberg, D.A., Blanchard, W., Smith, B., \& Barrow, E. (2012). Climate change, mean sea level and high tides in the Bay of Fundy. Atmosphere-ocean, 50(3), 261-276.

Gugliotta, M., \& Saito, Y. (2019). Matching trends in channel width, sinuosity, and depth along the fluvial to marine transition zone of tide-dominated river deltas: The need for a revision of depositional and hydraulic models. Earth-Science Reviews, 191, 93-113.

Gugliotta, M., Flint, S.S., Hodgson, D.M., \& Veiga, G.D. (2015). Stratigraphic record of river-dominated crevasse subdeltas with tidal influence (Lajas Formation, Argentina). Journal of Sedimentary Research, 85(3), 265-284.

Gugliotta, M., Saito, Y., Nguyen, V.L., Ta, T.K.O., Nakashima, R., Tamura, T., ... \& Yamamoto, S. (2017). Process regime, salinity, morphological, and sedimentary trends along the fluvial to marine transition zone of the mixed-energy Mekong River delta, Vietnam. Continental Shelf Research, 147, 7-26.

Helland-Hansen, W., \& Martinsen, O.J. (1996). Shoreline trajectories and sequences; description of variable depositional-dip scenarios. Journal of Sedimentary Research, 66(4), 670-688.

Helland-Hansen, W., \& Hampson, G.J. (2009). Trajectory analysis: concepts and applications. Basin Research, 21(5), 454-483.

Hess, K. (2003). Water level simulation in bays by spatial interpolation of tidal constituents, residual water levels, and datums. Continental Shelf Research, 23(5), 395-414.

Hill, D.F., Griffiths, S.D., Peltier, W.R., Horton, B.P., \& Törnqvist, T.E. (2011). High-resolution numerical modeling of tides in the western Atlantic, Gulf of Mexico, and Caribbean Sea during the Holocene. Journal of Geophysical Research, 116, C10014.

Holland, S.M., \& Wright, S.N. (2020). The Unconformity That Isn't: A Sequence-Stratigraphic Reinterpretation of the J-5 Unconformity and the Redwater-Windy Hill-Morrison Transition in Wyoming, USA. The Journal of Geology, 128(3), 247-274.

Hori, K., Saito, Y., Zhao, Q., \& Wang, P. (2002). Architecture and evolution of the tide-dominated Changjiang (Yangtze) River delta, China. Sedimentary Geology, 146(3-4), 249-264.

Hu, K., Ding, P., Wang, Z., \& Yang, S. (2009). A 2D/3D hydrodynamic and sediment transport model for the Yangtze Estuary, China. Journal of Marine Systems, 77(1-2), 114-136.

Idier, D., Paris, F., Le Cozannet, G., Boulahya, F., \& Dumas, F. (2017). Sea-level rise impacts on the tides of the European Shelf. Continental Shelf Research, 137, 56-71.

Imlay, R.W. (1947). Marine Jurassic of Black Hills area, South Dakota and Wyoming. American Association of Petroleum Geologists, Bulletin, 31(2), 227-273.

Imlay, R.W. (1952). Correlation of the Jurassic formations of North America, exclusive of Canada. Geological Society of America Bulletin, 63(9), 953-992. 
Imlay, R.W. (1980). Jurassic Paleobiogeography of the Conterminous United States in its Continental Setting. U.S. Geological Survey, Professional Paper, 1062, 134 pp.

James, N.P., \& Dalrymple, R.W. (Eds.). (2010). Facies Models 4. Geological Association of Canada, 575 pp.

Jensen, P.H., Sprinkel, D.A., Kowallis, B.J., \& Brown, K.D. (2016). Geologic Map of the Donkey Flat Quadrangle, Uintah County, Utah. Utah Geological Survey.

Jordan, O.D., \& Mountney, N.P. (2010). Styles of interaction between aeolian, fluvial and shallow marine environments in the Pennsylvanian to Permian lower Cutler beds, south-east Utah, USA. Sedimentology, 57(5), 1357-1385.

Jordan, O.D., \& Mountney, N.P. (2012). Sequence stratigraphic evolution and cyclicity of an ancient coastal desert system: the Pennsylvanian-Permian Lower Cutler Beds, Paradox Basin, Utah, USA. Journal of Sedimentary Research, 82(10), 755-780.

Kowallis, B.J., Hunt, J.E., Sprinkel, D.A., May, S.B., Bradfield, T.D., \& Brown, K.D. (2018). Geologic Map of the Lake Mountain Quadrangle, Uintah County, Utah. Utah Geological Survey, 801, 537-3300.

Kreisa, R.D., \& Moila, R.J. (1986). Sigmoidal tidal bundles and other tide-generated sedimentary structures of the Curtis Formation, Utah. Geological Society of America Bulletin, 97(4), 381-387.

Kresning, B., Hashemi, M.R., Neill, S.P., Green, J.M., \& Xue, H. (2019). The impacts of tidal energy development and sea-level rise in the Gulf of Maine. Energy, 187, 115942.

Kvale, E.P. (2006). The origin of neap-spring tidal cycles. Marine geology, 235(1-4), 5-18.

Kvale, E.P., \& Archer, A.W. (1991). Characteristics of two, Pennsylvanian age, semidiurnal tidal deposits in the Illinois Basin, USA. In: Smith, D.G., Reinson, G.E., Zaitlin, B.A., \& Rahmani, R.A. (Eds.), Clastic Tidal Sedimentology, Canadian Society Petroleum Geologists Memories, 16, 79-188.

Lentz, S., R. Guza, S. Elgar, F. Feddersen, and T. Herbers (1999), Momentum balances on the North Carolina inner shelf, J. Geophys. Res., 104, 18,205-18,226.

Longhitano, S.G., Mellere, D., Steel, R.J., \& Ainsworth, R.B. (2012). Tidal depositional systems in the rock record: a review and new insights. Sedimentary Geology, 279, 2-22.

Mallinson, D., Culver, S., Leorri, E., Mitra, S., Mulligan, R., \& Riggs, S. (2018). Pamlico Sound and the Outer Banks Barrier Islands, North Carolina, USA. In: Moore, L. \& Murray, A. (Eds.), Barrier Dynamics and Response to Changing Climate. Cham: Springer, 91-120.

Mansfield, G.R., \& Roundy, P.V. (1916). Revision of the Beckwith and Bear River Formations of southeastern Idaho. U.S. Geological Survey, Professional Paper, 98, 75-84

Mitchell, A.J., Allison, P.A., Gorman, G.J., Piggott, M.D., \& Pain, C.C. (2011). Tidal circulation in an ancient epicontinental sea: the Early Jurassic Laurasian Seaway. Geology, 39(3), 207-210.

Mountney, N.P. (2006). Periodic accumulation and destruction of aeolian erg sequences in the Permian Cedar Mesa Sandstone, White Canyon, southern Utah, USA. Sedimentology, 53(4), 789-823.

Müller, R. D., Cannon, J., Qin, X., Watson, R. J., Gurnis, M., Williams, S., Pfaffelmoser, T., Seton, N., Russel, S.H.J., \& Zahirovic, S. (2018). GPlates: building a virtual Earth through deep time. Geochemistry, Geophysics, Geosystems, 19(7), 2243-2261.

Mulligan, R.P., Perrie, W., \& Solomon, S. (2010). Dynamics of the Mackenzie River plume on the inner Beaufort shelf during an open water period in summer. Estuarine, Coastal and Shelf Science, 89(3), 214-220. 
Mulligan, R.P., Walsh, J.P., \& Wadman, H.M. (2015). Storm surge and surface waves in a shallow lagoonal estuary during the crossing of a hurricane. Journal of Waterway, Port, Coastal, and Ocean Engineering, 141(4), A5014001.

Mulligan, R.P., Smith, P.C., Tao, J., \& Hill, P.S. (2019a). Wind-wave and Tidally Driven Sediment Resuspension in a Macrotidal Basin. Estuaries and Coasts, 42(3), 641-654.

Mulligan, R.P., Mallinson, D.J., Clunies, G.J., Rey, A., Culver, S.J., Zaremba, N., et al. (2019b). Estuarine responses to long-term changes in inlets, morphology and sea level rise. Journal of Geophysical Research: Oceans, 124, 9235-9257.

Mulligan, R.P., Mallinson, D.J., Clunies, G.J., Rey, A., Culver, S.J., Zaremba, N., Leorri, E., \& Mitra, S. (2019). Estuarine Responses to Long-Term Changes in Inlets, Morphology, and Sea Level Rise. Journal of Geophysical Research: Oceans, 124(12), 9235-9257.

Parker, B.B. (2007). Tidal analysis and prediction, NOAA Spec. Publ. NOSCO-OPS 3, Silver Spring, Md. Patterson-Wittstrom, J. (1980). Stratigraphy of the Jurassic Stump Formation. Stratigraphy of Wyoming: 31st Annual Field Conference Guidebook, 91-100.

Pelling, H.E., \& Green, J.A.M. (2013). Sea level rise and tidal power plants in the Gulf of Maine. Journal of Geophysical Research: Oceans, 118(6), 2863-2873.

Pelling, H.E., Green, J.A.M., \& Ward, S.L. (2013). Modelling tides and sea-level rise: To flood or not to flood. Ocean Modelling, 63, 21-29.

Peterson, F. (1994). Sand dunes, sabkhas, streams, and shallow seas: Jurassic paleography in the southern part of the Western Interior Basin. In: Caputo, M.V., Peterson, J.A., \& Franczyk, K.J. (Eds.), Mesozoic Systems of the Rocky Mountain Region, USA, SEPM, Rocky Mountain Section, 233-272.

Phillips, S.P., Howell, J.A., Hartley, A.J., \& Chmielewska, M. (2020). Tidal estuarine deposits of the transgressive Naturita Formation (Dakota Sandstone): San Rafael Swell, Utah, USA. Journal of Sedimentary Research, 90(8), 777-795.

Pipiringos, G.N., \& O'Sullivan, R.B. (1978). Principal unconformities in Triassic and Jurassic rocks, western interior United States: a preliminary survey. U.S. Geological Survey, Professional Paper, 1035A, 1-29.

Pipiringos, G.N., \& Imlay, R.W. (Eds.) (1979). Lithology and subdivisions of the Jurassic Stump Formation in southeastern Idaho and adjoining areas. Geological Survey, Professional Paper, 1035-C, $1-25$.

Pugh, D., \& Woodworth, P. (2014). Sea-level science: Understanding tides, surges, tsunamis and mean sea-level changes. Cambridge University Press, Cambridge, 395 pp.

Räsänen, M.E., Linna, A.M., Santos, J.C., \& Negri, F.R. (1995). Late Miocene tidal deposits in the Amazonian foreland basin. Science, 269(5222), 386-390.

van Rijn, L.C. (1993). Principles of sediment transport in rivers, estuaries and coastal seas, Aqua publications, Amsterdam, $790 \mathrm{pp}$.

Rivers, J. M., Dalrymple, R. W., Yousif, R., Al-Shaikh, I., Butler, J. D., Warren, C., ... \& Bari, E. M. A. (2020). Mixed siliciclastic-carbonate-evaporite sedimentation in an arid eolian landscape: The Khor Al Adaid tide-dominated coastal embayment, Qatar. Sedimentary Geology, 408, 105730.

Rossi, V.M., Kim, W., Leva López, J., Edmonds, D., Geleynse, N., Olariu, C., ... \& Passalacqua, P. (2016). Impact of tidal currents on delta-channel deepening, stratigraphic architecture, and sediment bypass beyond the shoreline. Geology, 44(11), 927-930. 
Simon, B., \& Page, J. (2017). Tidal Constituants. Tides, Water Level and Currents Committee, International Hydrographic Organization (https://iho.int/mtg docs/com wg/IHOTC/IHOTC Misc/TWCWG Constituent list.pdf).

Sellwood, B. W., \& Valdes, P. J. (2006). Mesozoic climates: General circulation models and the rock record. Sedimentary geology, 190(1-4), 269-287.

Sleveland, A.R.N., Midtkandal, I., Galland, O., \& Leanza, H.A. (2020). Sedimentary architecture of storm-influenced tidal flat deposits of the upper Mulichinco Formation, Neuquén Basin, Argentina. Frontiers in Earth Science, 8, 219.

Sprinkel, D.A., Doelling, H.H., Kowallis, B.J., Waanders, G., \& Kuehne, P.A. (2011). Early results of a study of Middle Jurassic strata in the Sevier fold and thrust belt, Utah. In Sprinkel, D.A., Yonkee, W.A., \& Chidsey, T.C. Jr. (Eds.), Sevier Thrust Belt: Northern and Central Utah and Adjacent Areas, Utah Geological Association, Publication 40, 151-172.

Taylor, G.I. (1920). I. Tidal friction in the Irish Sea. Philosophical Transactions of the Royal Society of London. Series A, Containing Papers of a Mathematical or Physical Character, 220(571-581), 1-33.

Thorman, C. H. (2011). The Elko orogeny-A major tectonic event in eastern Nevada-western Utah. Sevier thrust belt-northern and central Utah and adjacent areas. In Sprinkel, D.A., Yonkee, W.A., \& Chidsey, T.C. Jr. (Eds.), Sevier Thrust Belt: Northern and Central Utah and Adjacent Areas, Utah Geological Association, Publication 40, 117-129.

Uhl, D., Jasper, A., \& Schweigert, G. (2012). Charcoal in the Late Jurassic (Kimmeridgian) of Western and Central Europe-palaeoclimatic and palaeoenvironmental significance. Palaeobiodiversity and Palaeoenvironments, 92(3), 329-341.

Uhlir, D.M., Akers, A., \& Vondra, C.F. (1988). Tidal inlet sequence, Sundance formation (upper Jurassic), north-central Wyoming. Sedimentology, 35(5), 739-752.

Wang, Y., Wang, Y.P., Yu, Q., Du, Z., Wang, Z.B., \& Gao, S. (2019). Sand-mud tidal flat morphodynamics influenced by alongshore tidal currents. Journal of Geophysical Research: Oceans, 124(6), 3818-3836.

Ward, S.L., Green, J.A.M., \& Pelling, H.E. (2012). Tides, sea-level rise and tidal power extraction on the European shelf. Ocean Dynamics, 62(8), 1153-1167.

Ward, S.L., Neill, S.P., Van Landeghem, K.J., \& Scourse, J.D. (2015). Classifying seabed sediment type using simulated tidal-induced bed shear stress. Marine Geology, 367, 94-104.

Ward, S.L., Scourse, J.D., Yokoyama, Y., \& Neill, S.P. (2020). The challenges of constraining shelf sea tidal models using seabed sediment grain size as a proxy for tidal currents. Continental Shelf Research, 205, 104165.

Wells, M. R., Allison, P.A., Hampson, G.J., Piggott, M.D., \& Pain, C.C. (2005a). Modelling ancient tides: the Upper Carboniferous epi-continental seaway of Northwest Europe. Sedimentology, 52(4), 715735.

Wells, M.R., Allison, P.A., Piggott, M.D., Pain, C.C., Hampson, G.J., \& De Oliveira, C.R. (2005b). Large sea, small tides: the Late Carboniferous seaway of NW Europe. Journal of the Geological Society, $162(3), 417-420$.

Wells, M.R. , Allison, P.A., Piggott, M.D., Gorman, G.J., Hampson, G.J., Pain, C.C., Fang, F. (2007), Numerical modelling of tides in the Late Pennsylvanian Midcontinent Seaway of North America with implications for hydrography and sedimentation, Journal of Sedimentary Research, 2007, Vol: 77, Pages: 843 - 865, doi:10.2110/jsr.2007.075. 
Wells, M.R., Allison, P.A., Piggott, M.D., Hampson, G.J., Pain, C.C., \& Gorman, G.J. (2010). Tidal modeling of an ancient tide-dominated seaway, part 2: the Aptian Lower Greensand seaway of Northwest Europe. Journal of Sedimentary Research, 80(5), 411-439.

Wilcox, W.T., \& Currie, B. (2008). Sequence Stratigraphy of the Jurassic Curtis, Summerville, and Stump formations, Eastern Utah and Northwest Colorado. In: Longman, M.W., \& Morgan, C.D. (Eds.), Hydrocarbon Systems and Production in the Uinta Basin, Utah, Rocky Mountain Association of Geologists and Utah Geological Association, Publication 37, 9-41.

Yalin, M.S., \& Karahan, E. (1979). Inception of sediment transport. Journal of the hydraulics division, 105(11), 1433-1443.

van Yperen, A.E., Holbrook, J.M., Poyatos-Moré, M., \& Midtkandal, I. (2019). Coalesced delta-front sheet-like sandstone bodies from highly avulsive distributary channels: the low-accommodation Mesa Rica Sandstone (Dakota Group, New Mexico, USA). Journal of Sedimentary Research, 89(7), 654-678.

van Yperen, A. E., Poyatos-Moré, M., Holbrook, J. M., \& Midtkandal, I. (2020). Internal mouth-bar variability and preservation of subordinate coastal processes in low-accommodation proximal deltaic settings (Cretaceous Dakota Group, New Mexico, USA). The Depositional Record, 6(2), 431-458.

Zuchuat, V., Sleveland, A., Sprinkel, D., Rimkus, A., Braathen, A., \& Midtkandal, I. (2018). New insights on the impact of tidal currents on a low-gradient, semi-enclosed, epicontinental basin-the Curtis Formation, east-central Utah, USA. Geology of the Intermountain West, 5, 131-165.

Zuchuat, V., Midtkandal, I., Poyatos-Moré, M., Da Costa, S., Brooks, H.L., Halvorsen, K., ... \& Braathen, A. (2019a). Composite and diachronous stratigraphic surfaces in low-gradient, transitional settings: The J-3 "unconformity" and the Curtis Formation, east-central Utah, USA. Journal of Sedimentary Research, 89(11), 1075-1095.

Zuchuat, V., Sleveland, A.R., Pettigrew, R.P., Dodd, T.J., Clarke, S.M., Rabbel, O., ... \& Midtkandal, I. (2019b). Overprinted allocyclic processes by tidal resonance in an epicontinental basin: The Upper Jurassic Curtis Formation, east-central Utah, USA. The Depositional Record, 5(2), 272-305. 